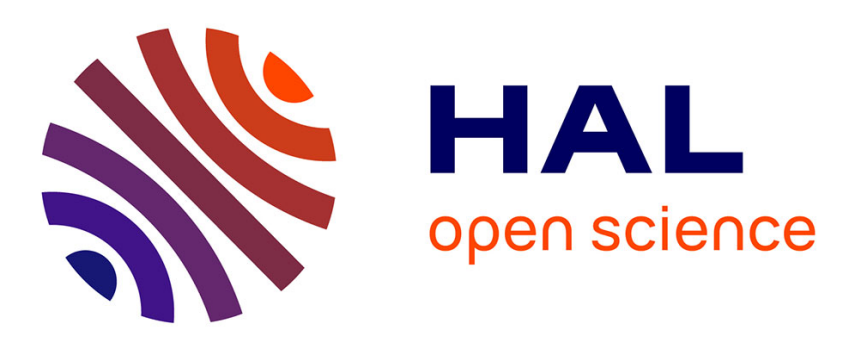

\title{
Depositional controls on a hypertidal barrier-spit system architecture and evolution, Pointe du Banc spit, north-western France
}

Mikkel Fruergaard, Bernadette Tessier, Clément Poirier, Dominique Mouazé, Pierre Weill, Suzanne Noël

\section{To cite this version:}

Mikkel Fruergaard, Bernadette Tessier, Clément Poirier, Dominique Mouazé, Pierre Weill, et al.. Depositional controls on a hypertidal barrier-spit system architecture and evolution, Pointe du Banc spit, north-western France. Sedimentology, 2020, 67 (1), pp.502-533. 10.1111/sed.12652 . hal02376512

\section{HAL Id: hal-02376512}

https://hal-normandie-univ.archives-ouvertes.fr/hal-02376512

Submitted on 5 Jan 2021

HAL is a multi-disciplinary open access archive for the deposit and dissemination of scientific research documents, whether they are published or not. The documents may come from teaching and research institutions in France or abroad, or from public or private research centers.
L'archive ouverte pluridisciplinaire HAL, est destinée au dépôt et à la diffusion de documents scientifiques de niveau recherche, publiés ou non, émanant des établissements d'enseignement et de recherche français ou étrangers, des laboratoires publics ou privés. 


\title{
Depositional controls on a hypertidal barrier-spit system architecture and evolution, Pointe du Banc spit, north-western France
}

\author{
MIKKEL FRUERGAARD*† (D), BERNADETTE TESSIER*, CLÉMENT POIRIER* \\ DOMINIQUE MOUAZÉ*, PIERRE WEILL* (D) and SUZANNE NOËL \\ *Normandie Université, UNICAEN, UNIROUEN, CNRS, M2C, 14000 Caen, France (E-mail: \\ mif@ign.ku.dk) \\ $\dagger$ Department of Geosciences and Natural Resource Management, University of Copenhagen, Øster \\ Voldgade 10, DK-1350 Copenhagen, Denmark \\ $\$$ Normandie Université, UNICAEN, Centre de Recherche d'Histoire Quantitative (CRHQ), 14000 Caen, \\ France
}

Associate Editor - Charlie Bristow

\begin{abstract}
Physical stratigraphy, architecture and evolution of barrier systems in hypertidal environments (tidal range above $6 \mathrm{~m}$ ) are understudied, and depositional controls are poorly understood compared with wave-dominated barrier systems and barrier spits in microtidal, mesotidal and macrotidal settings. Based on vibracores, ground-penetrating radar, radiocarbon and optically stimulated luminescence age data, the formation and evolution of the hypertidal barrier system of Pointe du Banc, north-western France has been reconstructed. The study shows that the barrier spit has a complex composite sedimentary architecture consisting of wave-dominated and tide-dominated sedimentary bodies. A morpho-sedimentary model is presented that demonstrates how barrier-spit progradation resulting from littoral drift was the main manner of spit elongation, whereas sediment convergence caused by landward migration of swash bars and seaward migration of tidal dunes caused the spit terminus to grow in height and width. These results suggest that long-term accretion rates varied considerably in response to changes in sediment supply. Variations in storminess together with the large-scale topography of the coast controlled the sediment supply and thus the evolution of the barrier system during latest Holocene. Despite architectural complexity, hypertidal barrier systems preserve records of past climate changes.
\end{abstract}

Keywords Coastal evolution, depositional controls, ground-penetrating radar, increased storminess and sediment supply, North-West France, optically stimulated luminescence dating.

\section{INTRODUCTION}

Understanding barrier spit formation and evolution is increasingly important in order to assess how these soft-sediment coastal systems will respond and adapt to expected future changes in storm intensity and sea level (von Storch \& Woth, 2008; Seneviratne et al., 2012; Church et al., 2013; Grinsted et al., 2013). The evolution of barrier spits is the result of complex interactions between wave and tide dynamics (Evans, 1942; Hine, 1979; Allard et al., 2008; Lindhorst et al., 2008; Nielsen \& Johannessen, 2009; Dalrymple et al., 2012; Poirier et al., 2017), fluctuations in sea level (Kraft, 1971; Colman \& Mixon, 1988; Van Heteren \& Van De Plassche, 1997; 
Fruergaard et al., 2015a; Sander et al., 2016), the impact of storms (Sexton \& Hayes, 1991; Morton \& Sallenger, 2003; Dougherty et al., 2004; Fruergaard et al., 2013; Fruergaard \& Kroon, 2016), sediment supply (Aagaard et al., 2004a; Timmons et al., 2010; Fruergaard et al., 2015b; Oliver et al., 2017; Fruergaard et al., 2018), and geological and morphological inheritance (Belknap \& Kraft, 1985; Riggs et al., 1995; Dillenburg et al., 2000; Cooper et al., 2012; Sander et al., 2015; Cooper et al., 2018). To predict barrier spit evolution, it is a prerequisite to have detailed knowledge about their geomorphology, sedimentary architecture and depositional history.

Several studies investigated the sedimentary evolution of microtidal, mesotidal and macrotidal (tidal range between $0 \mathrm{~m}$ and $6 \mathrm{~m}$; Davis, 1964) barrier spits (Hine, 1979; Fitzgerald et al., 1984; Nielsen et al., 1988; Bristow et al., 2000; Daly et al., 2002; Allard et al., 2008; Lindhorst et al., 2008; Nielsen \& Johannessen, 2009; Garrison et al., 2010; Lindhorst et al., 2010; Reimann et al., 2011; Fruergaard et al., 2015a; Sander et al., 2018), whereas only a few dealt with their hypertidal (tidal range above $6 \mathrm{~m}$; Archer, 2013) counterparts (Isla et al., 1991; Lessa \& Masselink, 2006; Billeaud et al., 2007; Robin et al., $2009 \mathrm{~b})$. To the knowledge of the authors, no studies have investigated the internal architecture of barrier spits, which formed under hypertidal conditions. Current understanding of the depositional controls and how climate-induced changes in hydrodynamic conditions are preserved in the sedimentary record of such environments can therefore be improved.

Barrier spit sedimentation is mainly controlled by wave-induced currents resulting in longshore and cross-shore sediment transport. These processes induce downdrift and seaward spit progradation. The main wave-built architectural elements may include spit platforms, swash and nearshore bars, berms, foreshores and backshores, beach ridges, washover channels and fans (e.g. Clifton, 1969; Hine, 1979; Dabrio, 1982; Nielsen et al., 1988; Bristow et al., 2000; Kroon \& Masselink, 2002; Lindhorst et al., 2008; Garrison et al., 2010; Billy et al., 2014). Architectural elements associated with tidal currents are less common. However, they are usually well-developed at tidal inlets, even in microtidal environments, due to enhanced tidal currents in the channel (e.g. Nielsen et al., 1988; Mallinson et al., 2010). Barrier spits in hypertidal settings have many architectural elements in common with spits located in wave-dominated areas but the strong tidal currents generally associated with these environments, as well as the very large lateral and vertical extension of tide and wave actions due to the very large tidal range, are expected to produce a complex composite wave-influenced and tide-influenced architecture. This may complicate or prevent inferring a specific depositional control mechanism from such deposits.

With a tidal range exceeding $13 \mathrm{~m}$ and lowenergy wave conditions, the central part of the western coast of the Cotentin peninsula along the Central English Channel in north-western France (Fig. 1A) provides an opportunity to study barrier spit stratigraphy, architecture and evolution under mixed wave-conditions and tide-conditions. This study applies ground penetrating radar (GPR), sediment cores, optically stimulated luminescence (OSL) and radiocarbon dating as well as geodata and historical maps to examine the sedimentology and evolution of the hypertidal Pointe du Banc (PDB) barrier spit. Specifically, the aims of this study are: (i) to evaluate the morphology, stratigraphy and architecture of the hypertidal PDB barrier spit; (ii) to analyse the long-term temporal evolution of the study site; (iii) to propose a sedimentological model for the formation of the spit; (iv) to discuss variations between the proposed model and existing sedimentological spit models; and (v) to discuss the evolution of hypertidal spits in relation to changes in hydrodynamics, antecedent topography and sediment supply.

\section{REGIONAL SETTING}

The PDB barrier spit and the estuary of Havre de Lessay (HDL) is part of the coastal foreland on the north-south oriented shoreline of the western Cotentin peninsula located along the English Channel coast, north-western France (Fig. 1A and B). The large-scale morphology of the coastal foreland is controlled by the rocky Armorican Massif, which forms a large shallow embayment between two rocky headlands at Barneville-Carteret to the north and Granville to the south (Fig. 1B; Doré \& Poncet, 1974). Between the two headlands, the coast is composed of eight barrier spit systems with the PDB barrier spit located approximately in the central and innermost part of the embayment. The present-day coastal landscape and littoral wedge of the western Cotentin peninsula was formed under the influence of the post-glacial relative 

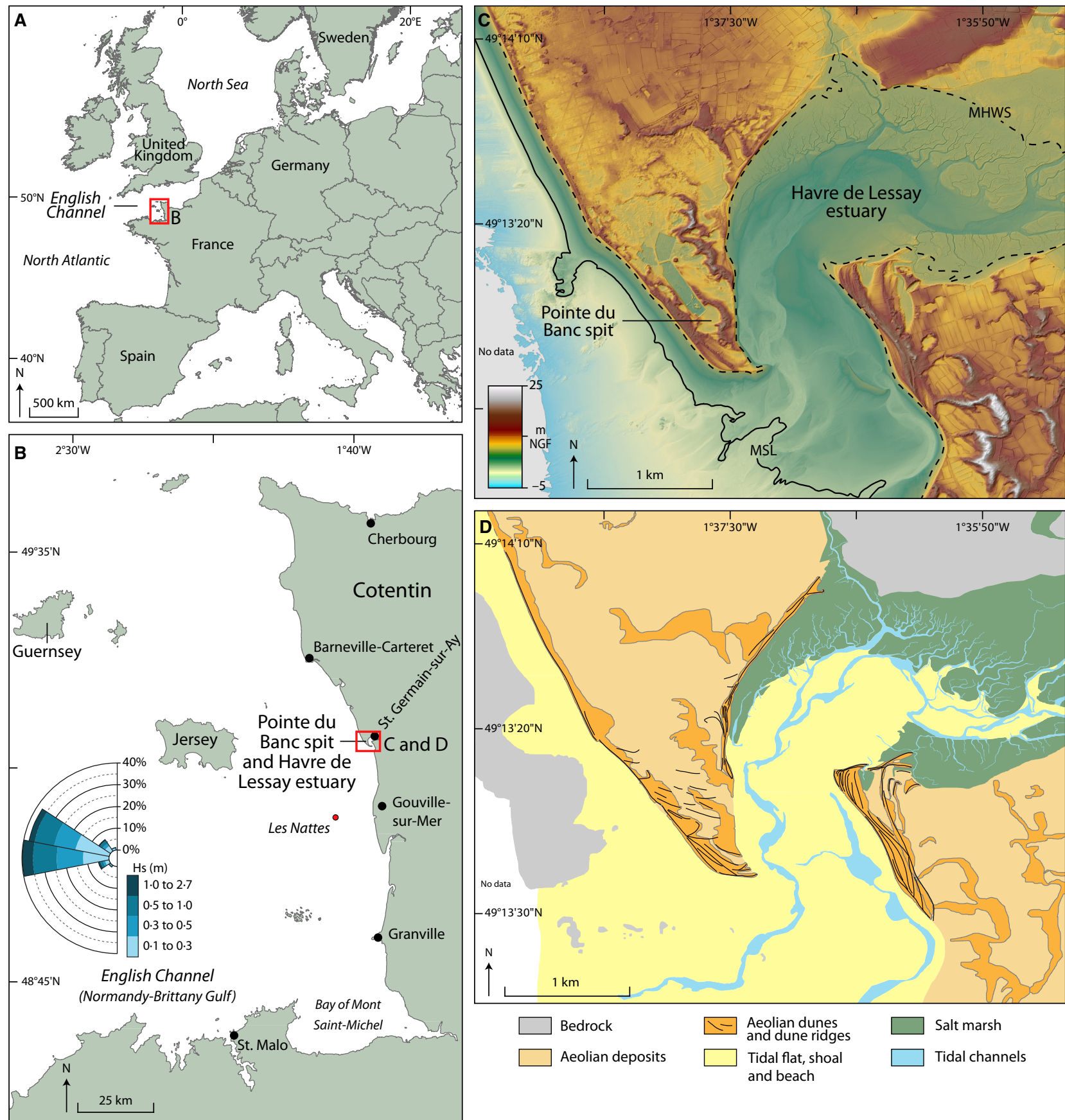

Fig. 1. (A) The study site along the coast of the English Channel in north-western France. (B) The Pointe du Banc (PDB) spit at the north-south oriented coast of the Cotentin peninsula. Annual offshore significant wave height (Hs) from Les Nattes is modified after Montreuil et al. (2014). (C) Light detection and ranging (LiDAR)-based digital terrain model (DTM) of the PDB spit and the estuary of Havre de Lessay with elevations relative to the Nivellement Général de la France (NGF): 0.681 m and 5.76 m NGF correspond to mean sea level (MSL; plain black line) and mean high water spring tide level (MHWS; dashed black line), respectively. (D) Morpho-sedimentary surface map of the study site.

sea-level (RSL) rise (Fig. 2). About 10 ka the sea level was more than $40 \mathrm{~m}$ below the present-day level, and until 6000 вр rose by about $11 \mathrm{~mm} \mathrm{year}^{-1}$ (Lambeck, 1997), which caused the shoreline in the area to retreat rapidly. From 6000 years BP RSL rise slowed down significantly and shorelines stabilised or retreated more gradually. During the last approximately 
6000 years sea level increased between $3 \mathrm{~m}$ and $6 \mathrm{~m}$ at a near-constant rate of 0.5 to $1.0 \mathrm{~mm}$ year $^{-1}$ (Lambeck, 1997; Tessier et al., 2012).

The tidal regime of the study area is semidiurnal and tidal resonance produces tidal ranges up to about $13 \mathrm{~m}$ during highest spring tides. Mean tidal range is about $10 \mathrm{~m}$ (SHOM, 2013). The tide generates strong currents up to $1 \mathrm{~m} \mathrm{sec}^{-1}$ off the west Cotentin coast and up to $3 \mathrm{~m} \mathrm{sec}^{-1}$ in the mouth of the HDL estuary (Levoy et al., 2000). Tidal currents are mostly parallel to the coast with northward-directed currents during the flood phase and southward-directed currents during the ebb phase. Westerly and north-westerly winds dominate the area in winter. The western coast of the Cotentin peninsula is exposed to waves and swells from the English Channel and the North Atlantic Ocean, but the PDB barrier spit is regarded as a low-energy shoreline due to the shallow depth of the Normandy-Brittany Gulf and the lee-effect generated by the Channel Islands and various shoals and islets (Fig. 1B). The annual mean significant offshore wave height is less than $0.5 \mathrm{~m}$ (Ehrhold, 1999) but, during storms, waves and swells may increase considerably and the maximum annual significant wave height offshore of Barneville-Carteret is about $4.2 \mathrm{~m}$, decreasing to about $2.8 \mathrm{~m}$ offshore of Granville (Levoy et al., 2000; Fig. 1B).

The PDB is a roughly triangular-shaped barrier spit that is about $1.6 \mathrm{~km}$ long and about $1.2 \mathrm{~km}$ wide at its proximal end where it attaches to the

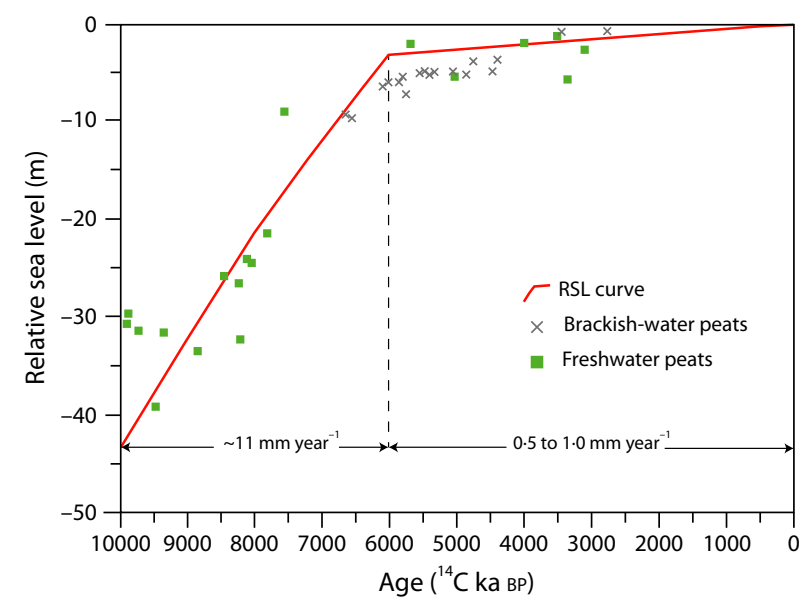

Fig. 2. Predicted relative mean sea level in Normandy, northern France, and sea-level indicators from Lambeck (1997). During the last 6000 years sea level has increased annually by 0.5 to $1.0 \mathrm{~mm}$. coastal foreland. The spit terminus recurves eastward into the HDL estuary. The spit is currently eroding and the seaward shoreline is retreating. The HDL estuary is fed by the river Ay. This is a small river with a mean discharge less than $1 \mathrm{~m}^{3} \mathrm{sec}^{-1}$ and an insignificant sediment discharge to the estuary (Avoine \& Larsonneur, 1987; Banque-Hydro, 2018). Most finegrained deposits contributing to the mudflat and salt marsh development within the estuary are of marine origin. They are mixed siliciclastic carbonated silt-dominated sediments, typical for the estuarine infillings along the west Cotentin coast, including the Bay of Mont Saint-Michel (Bourcart \& Charlier, 1959; Larsonneur, 1994).

At the spit terminus, a $c a 1.5 \mathrm{~km}$ wide and shallow $(<1 \mathrm{~m}$ at low tide) tidal inlet connects the estuary with the sea. The inlet morphology is changing rapidly due to the very dynamic nature of the constantly migrating tidal channels. Sand shoals with tidal dunes and tidal channels compose the central part of the estuary, whereas salt marsh and salt marsh creeks occupy the fringes of the estuary (Fig. 1D).

The typical seaward beach profile of the PDB spit is about $1000 \mathrm{~m}$ wide and featureless, lacking a well-developed ridge and runnel morphology. The profile is concave-shaped and it can be divided into a relatively steep ( $\beta=0.07$ to 0.12 ) high-tidal zone, a moderately sloping $(\beta=0.015$ to 0.03) mid-tidal zone and a flat $(\beta=0.005)$ low-tidal zone (Levoy et al., 2000).

\section{MATERIALS AND METHODS}

\section{Geodata and maps}

The construction of the morpho-sedimentary map and the identification of coastal landforms and depositional environments of the PDB spit were based on analysis of a LiDAR-derived digital terrain model (DTM) with a resolution of $1 \mathrm{~m}$ and a vertical precision of $\pm 0 \cdot 15 \mathrm{~m}$ (RGE ALTI, Institut Géographique National). In addition 20 digital orthophotographs temporally spanning from 1935 to $2014 \mathrm{CE}$ and five historical maps from $1545 \mathrm{CE}, 1670 \mathrm{CE}, 1689 \mathrm{CE}, 1764 \mathrm{CE}$ and 1834 to $1839 \mathrm{CE}$ were used to reconstruct the historical development of the system. The historical maps were georectified and digitised, but because of large uncertainties related to the accuracy of the maps, only large-scale shoreline changes can be inferred from comparison of the maps: ESRI ArcGIS 10.1 (Redlands, California, 
USA) was used for all analysis and visualisations of the data, and ground-truthing in the field was conducted for all inferences based on the geodata. All elevation data presented in this study are relative to Nivellement Général de la France (NGF) datum, which approximately corresponds to present-day mean sea level at the study site.

\section{Studies of modern depositional environments}

The geomorphology of the barrier spit was studied in the field through the aid of the DTM and aerial photographs on the basis of which distinct depositional environments were mapped. The sedimentary deposits of each environment were investigated in terms of lithology, grain size and physical structures. The DTM was used to study the morphology and determine the geographical extent and the elevation of the depositional environments relative to one another and to mean sea level. Such analyses are necessary to recognise and interpret sediment core and radar data.

\section{Ground-penetrating radar}

The internal architecture and stratigraphy of the PDB spit was investigated using a GPR SIR-3000 system from Geophysical Survey Systems, Inc. (Nashua, New Hampshire, USA) equipped with a $400 \mathrm{MHz}$ shielded antenna providing an average vertical resolution of about $0.15 \mathrm{~m}$ (Weill et al., 2012). More than $30 \mathrm{~km}$ of GPR lines were collected from the PDB spit. The average penetration depth was between $4 \mathrm{~m}$ and $6 \mathrm{~m}$, reaching up to $c a 8 \mathrm{~m}$ (Fig. 3). The spatial position of the GPR data was determined with a continuous tracking Garmin GPSmap 78 (Garmin, Schaffhausen, Switzerland). Processing of the GPR data was carried out with custom scripts implemented in open-source software $\mathrm{R}$, and included: (i) adjustment of the time zero position for removal of the top reflector corresponding to the direct air and ground waves; (ii) enhancement of the 'signal to noise' ratio through a Karhunen-Loève filter (e.g. Jones \& Levy, 1987); (iii) amplitude correction; (iv) time to depth conversion; and (v) static migration for topographic correction (Dujardin \& Bano, 2013). Topographic correction of the GPR profiles was performed by using the extracted elevations from the DTM model. Time to depth conversion was done by applying a velocity model with radar wave velocities based on median values of the relative dielectric permittivity for unsaturated sand $\left(\varepsilon_{\mathrm{r}}=5\right)$ and for saturated sand $\left(\varepsilon_{\mathrm{r}}=26\right)$ from Neal \& Roberts (2000) that yield average radar wave velocities of $c a 0.15 \mathrm{~m} \mathrm{~ns}^{-1}$ (unsaturated sand) and $c a 0.06 \mathrm{~m} \mathrm{~ns}^{-1}$ (fully saturated sand). These values are comparable to wave velocities found in similar coastal settings (Nielsen et al., 2009; Lindhorst et al., 2010; Fruergaard et al., 2015b).

The level of the groundwater table was roughly estimated from the mean surface levels of ponds located in the study area to $4.7 \mathrm{~m}$ NGF. In the velocity model, it is assumed here that the sediment water saturation is progressively increasing from $1.5 \mathrm{~m}$ above the water table and down to the water table. To test the model and topographic correction, the corrected GPR data were compared to the sediment core data. A good correlation $( \pm 0.3 \mathrm{~m})$ was found between distinct organic rich sediment layers and marked GPR reflections. The accuracy of the model applied in dry sand was further tested by comparing the measured depth of a metallic object buried in the aeolian dunes with the depth found based on GPR data corrected with the velocity model. The result of the test was within the vertical resolution of $0.15 \mathrm{~m}$ and supports the overall accuracy of the depth conversion in the topmost part of the subsurface.

Because the focus of this study was on the marine sediments of the barrier spit, the GPR

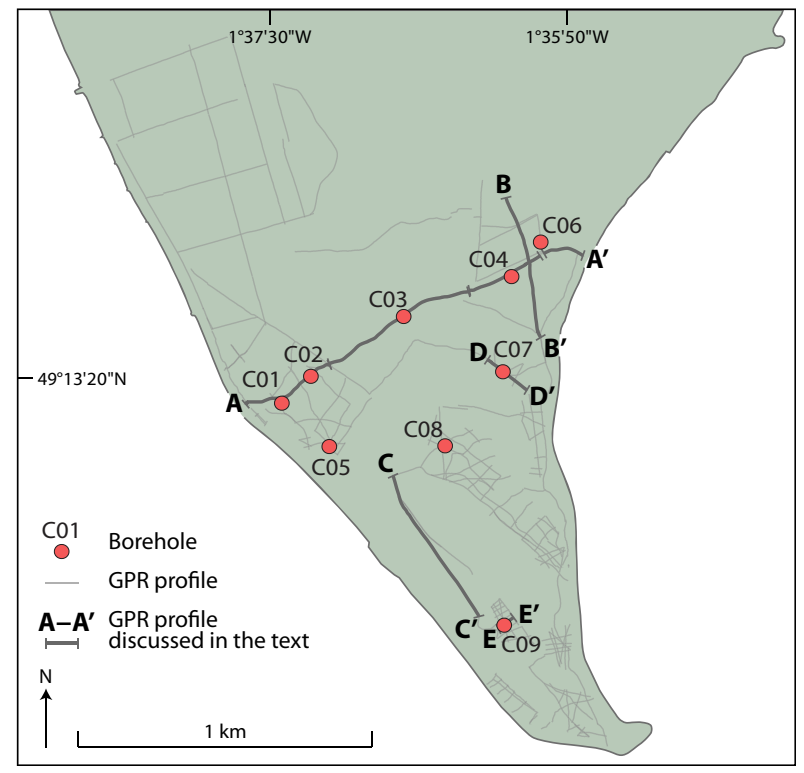

Fig. 3. Map showing the location of boreholes and ground penetrating radar (GPR) profiles at the Pointe du Banc Spit. 
profiles are cut off at $10 \mathrm{~m}$ NGF. Only aeolian deposits were present in the profiles above the cut-off limit.

\section{Vibracoring and core processing}

To investigate the sedimentology of the PDB spit, nine nearly undisturbed vibracores ranging between $3.5 \mathrm{~m}$ and $5.0 \mathrm{~m}$ in length were collected. Five cores were taken along a shore-normal transect at the proximal part of the spit, and four cores were evenly distributed on the central and distal part of the spit (Fig. 3). All cores were acquired from topographically low interdune areas to avoid coring through thick aeolian successions that would limit the recovery of marine deposits. The vibracore system consisted of a powered pneumatic drill mounted on a $6 \mathrm{~m}$ high rig. Sediment recovery was almost $100 \%$ and compaction very limited $(<10 \mathrm{~cm}$ over $5 \mathrm{~m}$ long cores). In the laboratory the cores were cut lengthwise, split, photographed and logged (visually-determined grain size, physical and biogenic structures, bedding, colours and fossils).

\section{Absolute chronology}

Geochronology was provided by accelerator mass spectrometry (AMS) radiocarbon and optically stimulated luminescence (OSL) dating. Thirtyfive shell and organic sediment samples were radiocarbon dated at the Poznan Radiocarbon Laboratory in Poland. The conventional radiocarbon ages were calibrated using CALIB v. 7.1 (Stuiver \& Reimer, 1993; Stuiver et al., 2005) with the MARINE13 calibration curve (Reimer et al., 2013). The marine reservoir correction database was used (Reimer \& Reimer, 2001) with data from Tisnérat-Laborde et al. (2010) to determine the average reservoir age in the NormandyBrittany Gulf (Fig. 1). An inverse error-weighted mean of nine $\Delta \mathrm{R}$ values from sites located within $c a 70 \mathrm{~km}$ of the study area yielded an average $\Delta \mathrm{R}$ of $-28 \pm 96$ years, which was applied as a best estimate for the samples from the PDB spit. Calibrated radiocarbon ages are reported in calendar years before present (вР) relative to $1950 \mathrm{CE}$ with a 2-sigma uncertainty.

Thirteen sediment samples were OSL dated at the Nordic Laboratory for Luminescence Dating, Aarhus University, Denmark. The samples were collected from the cores under subdued red light and wrapped in lightproof plastic. Before sampling, the surface sediment of the core halves was removed down to a depth of about $2 \mathrm{~cm}$.
This was done to ensure that all sediment that potentially had been exposed to daylight and bleaching during storage was removed. Stainless steel discs mounted with pure quartz extract were measured on automated Risø TL/OSL readers (DTU Nutech, Roskilde, Denmark; Bøtter-Jensen et al., 2000, 2002) and the single aliquot regenerative dose (SAR) protocol was used to obtain the equivalent dose $\left(D_{\mathrm{e}}\right)$ (Murray \& Wintle, 2000, 2003). The radionuclide concentrations were measured using high-resolution gamma-ray spectrometry (Murray et al., 1987) and converted to dry matrix dose rates using conversion factors from Guérin et al. (2011). The field and saturated water content (mass of water to mass of dry sample), was determined for each sample and used to reduce the dose rates. The field water content was applied to the uppermost sample from each core and the saturated water content was applied to the additional samples. The OSL ages are reported relative to the year $1950 \mathrm{CE}$ with a 1-sigma uncertainty. The relative error of the age estimate ranges between $6 \%$ and $12 \%$ with an average error of $8 \%$.

\section{RESULTS AND INTERPRETATIONS}

\section{Morphology and sedimentology of modern depositional environments}

From the seaward-side of the PDB spit to the bedrock in the inner part of the HDL estuary, six active and inactive depositional environments were identified: (i) intertidal ebb-tidal delta with current-ripples, wave-ripples and combined flowripples and tidal channels; (ii) beach; (iii) spit with dune ridges, parabolic dunes and swales; (iv) spit terminus with tidal dunes; (v) estuary with tidal channels, tidal shoals with tidal dunes; and (vi) salt marsh with creeks (Fig. 4). In front of the estuary mouth, a 4 to $5 \mathrm{~km}^{2}$ large ebb tidaldelta gently dips seaward $(\beta=0 \cdot 002)$. The elevation of the delta ranges from about 0.7 to $-2.6 \mathrm{~m}$ NGF. Current-ripples varying in height from a few centimetres up to 5 to $10 \mathrm{~cm}$, shallow ( $<50 \mathrm{~cm}$ deep) tidal channels, transverse bars, swash bars and exposed bedrock occupy the surface of the delta (Levoy et al., 2013; Montreuil et al., 2014) (Fig. 5A and B). It is mainly composed of fine to coarse-grained sand and shell fragments, while pebbles and larger shells are observed at the bed of the ebb delta channels.

Depending on the tide, the width of the beach between the ebb-tidal delta and the dune ridges 


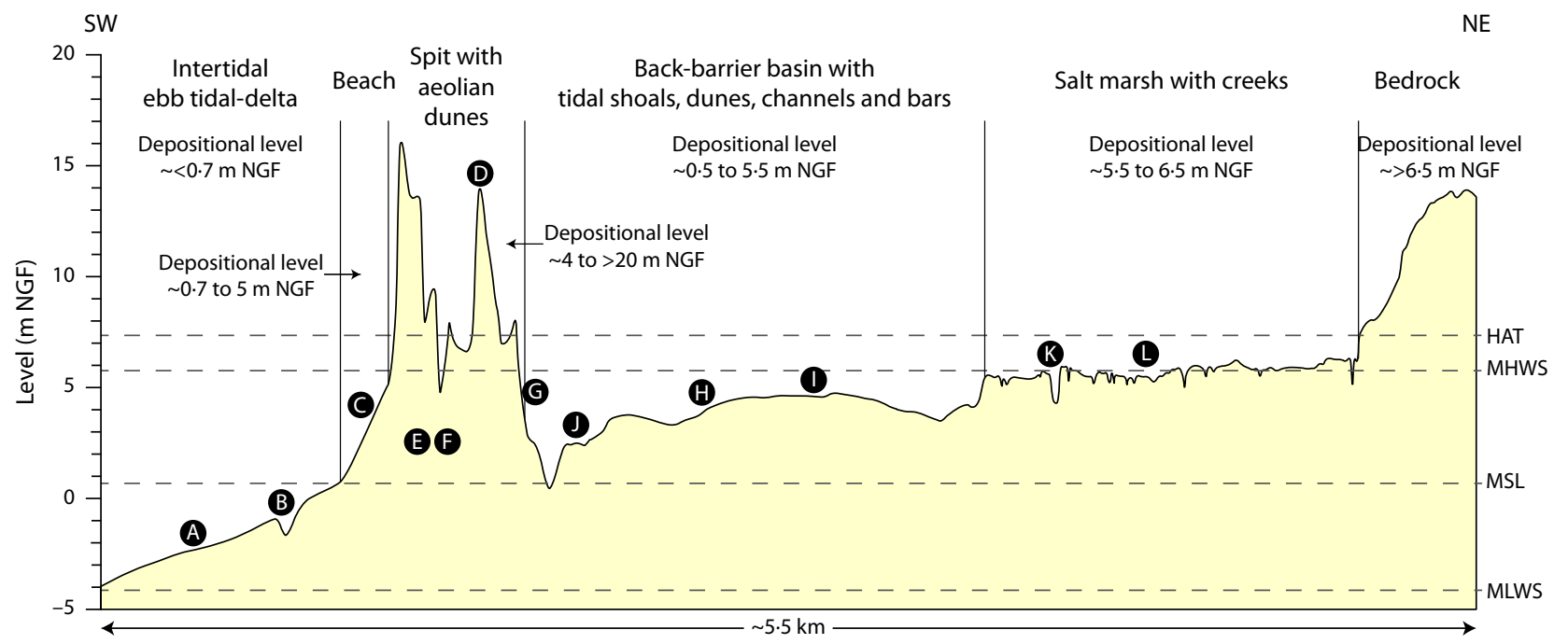

Fig. 4. Schematic cross-shore profile illustrating the main modern depositional environments at the study site and their elevation relative to Nivellement Général de la France (NGF) vertical datum. The levels of highest astronomical tide (HAT), mean high water spring tide (MHWS), mean sea level (MSL) and mean low water spring tide (MLWS) are indicated. The letters (A to L) show the approximate positions of the photographs in Fig. 5.

of the PDB spit ranges from a few metres to more than hundred metres. The elevation of the beach ranges from about 0.7 to $5.0 \mathrm{~m} \mathrm{NGF}$ and it slopes about $\beta=0.002$ seaward. It is nearly featureless except for minor embryonic dunes along the foot of the dune ridge. The beach is composed of fine to medium-grained sand covered by angular pebbles and cobble clasts (Fig. 5C).

The spit, except for its terminus, is dominated by vegetation-covered coastal dune ridges and parabolic dunes that range in elevation from $4 \mathrm{~m}$ to $>20 \mathrm{~m}$ NGF (Fig. 5D). Coast-parallel foredunes fringe the open-ocean and the back-barrier shorelines, whereas parabolic dunes cover most of the central parts of the spit (Fig. 1C and D). Several buried spits and intervening swales can be identified in the surface morphology of the spit despite the aeolian cover (Fig. 1C and D). The elevation of the spit terminus is between $1.5 \mathrm{~m}$ and $7.0 \mathrm{~m} \mathrm{NGF}$, its surface being covered at low tide by ebb-oriented three-dimensional tidal dunes with 30 to $50 \mathrm{~cm}$ high slip faces and scour pits (Figs 5E, 5F, 6A and 6B). The spit terminus cross-sectional profile is asymmetrical with a steep ( $\beta=0.09)$ landward side and a gently sloping seaward ( $\beta=0.04)$ side (Figs $5 \mathrm{G}, 6 \mathrm{C}$ and $6 \mathrm{D}$ ). The spit terminus is mainly composed of fine to coarse-grained sand with abundant pebbles, cobbles and shells.

Between 2005 and 2006, the spit terminus was breached and became detached from the spit. In the following years, it migrated as a swash bar across the mouth of the estuary and eventually merged with the opposite coast (Fig. 7). The length and width of the asymmetrical swash bar was about $500 \mathrm{~m}$ and $110 \mathrm{~m}$, respectively, and it had a height of 1.5 to $2 \cdot 0 \mathrm{~m}$.

Very fine to coarse-grained tidal shoals with pebbles and abundant shell fragments that range in elevation from about 0.5 to $6.0 \mathrm{~m}$ NGF compose the main part of the estuary and estuary mouth (Fig. 5H). While tidal bedforms are frequently observed in the estuary, almost featureless tidal shoals are seen along the highest elevation parts of the estuary. The dominant bedforms in the estuary are two-dimensional tidal dunes and current ripples (Fig. 5I and J). Tidal dunes with $30 \mathrm{~cm}$ high slip faces are mostly observed in the tidal channels where tidal energy is highest. The tidal shoals covered by current ripples are mostly observed along the fringes of the estuary where tidal energy is lower. A thin mud drape deposited during highwater slack tide often covers the current ripples (Fig. 5J). Migrating tidal channels cut the tidal shoals. The planform geometry of the channels is continuously changing due to the highly variable conditions of water and sediment discharge caused by tidal dynamics.

Salt marsh and tidal creeks occupy the inner and highest-lying parts of the estuary (Fig. 5K and L). The salt marsh can be divided into a high and low salt marsh, the former being situated at about $5.5 \mathrm{~m} \mathrm{NGF}$, the latter at about $6.0 \mathrm{~m} \mathrm{NGF}$, 

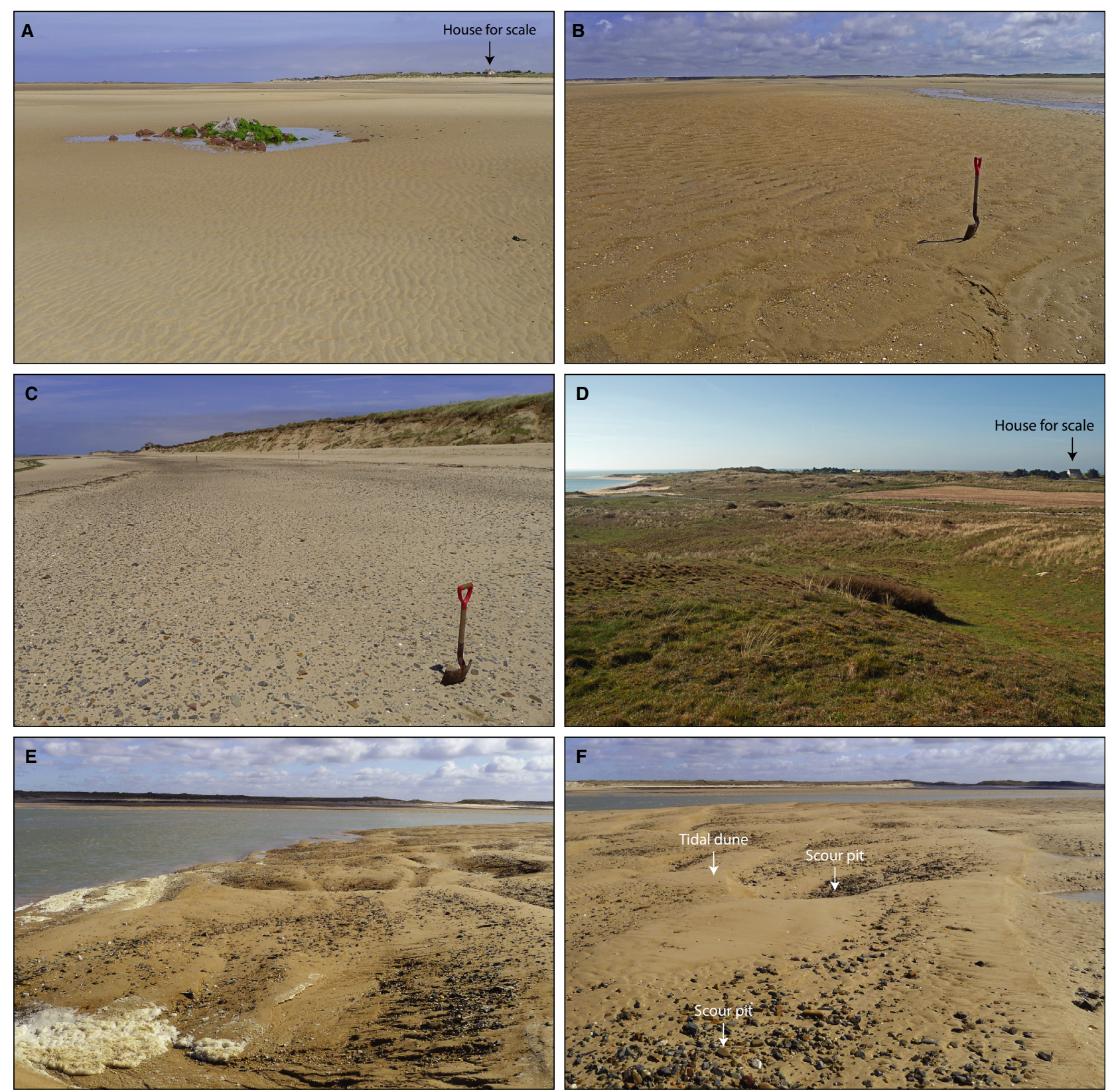

Fig. 5. Photographs showing the modern depositional environments from the open-ocean side of the Pointe du Banc (PDB) spit to the inner part of the estuary (see Fig. 4). (A) Intertidal ebb-tidal delta with current ripples and exposed bedrock. (B) Intertidal ebb-tidal delta with ebb-oriented current ripples. Shelly material deposits in the troughs between the ripple crests. (C) Beach backed by an erosive aeolian dune ridge on the open-ocean side of the spit. The surface of the beach is covered by a pebble and cobble pavement because aeolian processes removed the sand. The height of the shovel in (B) and (C) is $c a 1 \mathrm{~m}$. (D) Vegetation-covered aeolian dune ridges and swales at the spit. (E) Ebb-oriented three-dimensional tidal dunes with scour pits at the spit terminus. (F) Scour pits with accumulation of coarse-grained sand, shells and pebbles. The horizontal field of view along the lower edge of the photographs in (E) and (F) is ca $2 \mathrm{~m}$.

i.e. slightly above the MHWS tide level at $5 \cdot 76 \mathrm{~m}$ NGF, and up to $6.5 \mathrm{~m} \mathrm{NGF}$. The sediment of the salt marsh is composed of clay, silt and finegrained sand with abundant roots and gastropod shells of Peringia (formerly Hydrobia) ulvae.

\section{Core facies, radar units and depositional units}

The deposits of the PDB barrier spit and HDL estuary were separated into six core facies and 12 

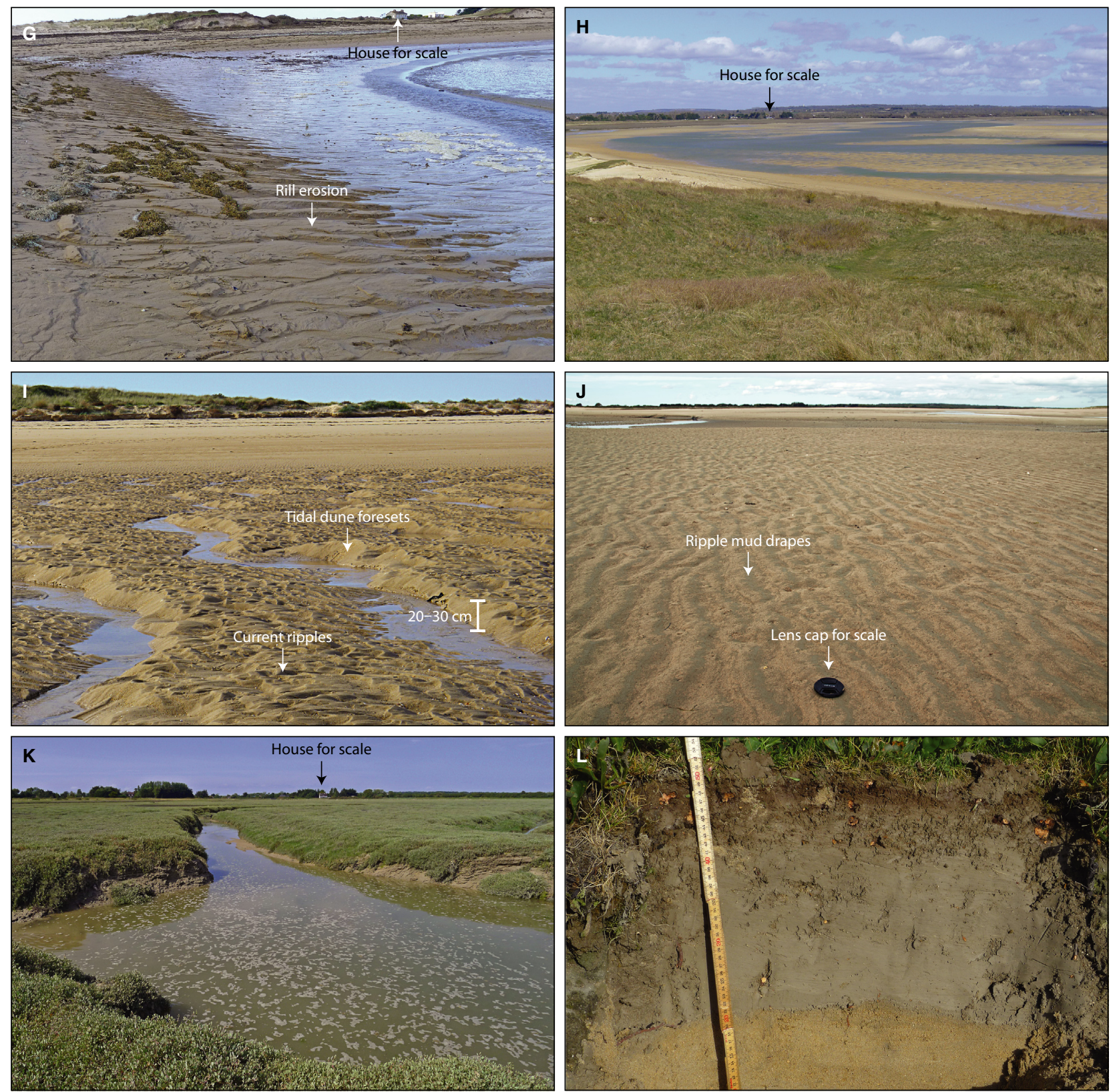

Fig. 5. Continued. (G) Rill erosion along the landward side of the spit terminus. The main tidal channel in the PDB estuary can be seen in the right-hand side of the photograph. (H) Tidal shoals with tidal dunes and tidal channels in the estuary. (I) Ebb-oriented tidal dunes covered by late-stage current ripples along the back-barrier shoreline. Shelly material accumulates in the troughs between the dune crests. (J) Long-crested current ripples with mud drapes on the lee-side and troughs of the ripples. The diameter of the lens cap is $c a 6 \mathrm{~cm}$. (K) Low salt marsh with salt marsh creeks. (L) Low salt marsh profile showing fine to medium-grained sand overlain by $c a$ $30 \mathrm{~cm}$ of clay and silt with Peringia ulvae and roots. The scale of the ruler is marked in centimetres.

radar units described and illustrated in Table 1 and Figs 8 and 9. The core facies and radar units were grouped into: (i) an aeolian unit; (ii) a barrier unit composed of both wave-dominated and tide-dominated sandy deposits; and (iii) an estuarine unit, which is mainly composed of tidedominated sandy and muddy deposits.

\section{Aeolian unit}

Core facies CF1 and radar units RU1 to RU4 form the aeolian unit: The aeolian sediments were deposited in the form of various bedforms that can be discriminated from their internal stratification and bedding planes (Hunter, 1977; Kocurek, 1996; Bristow, 2009). The mounded 

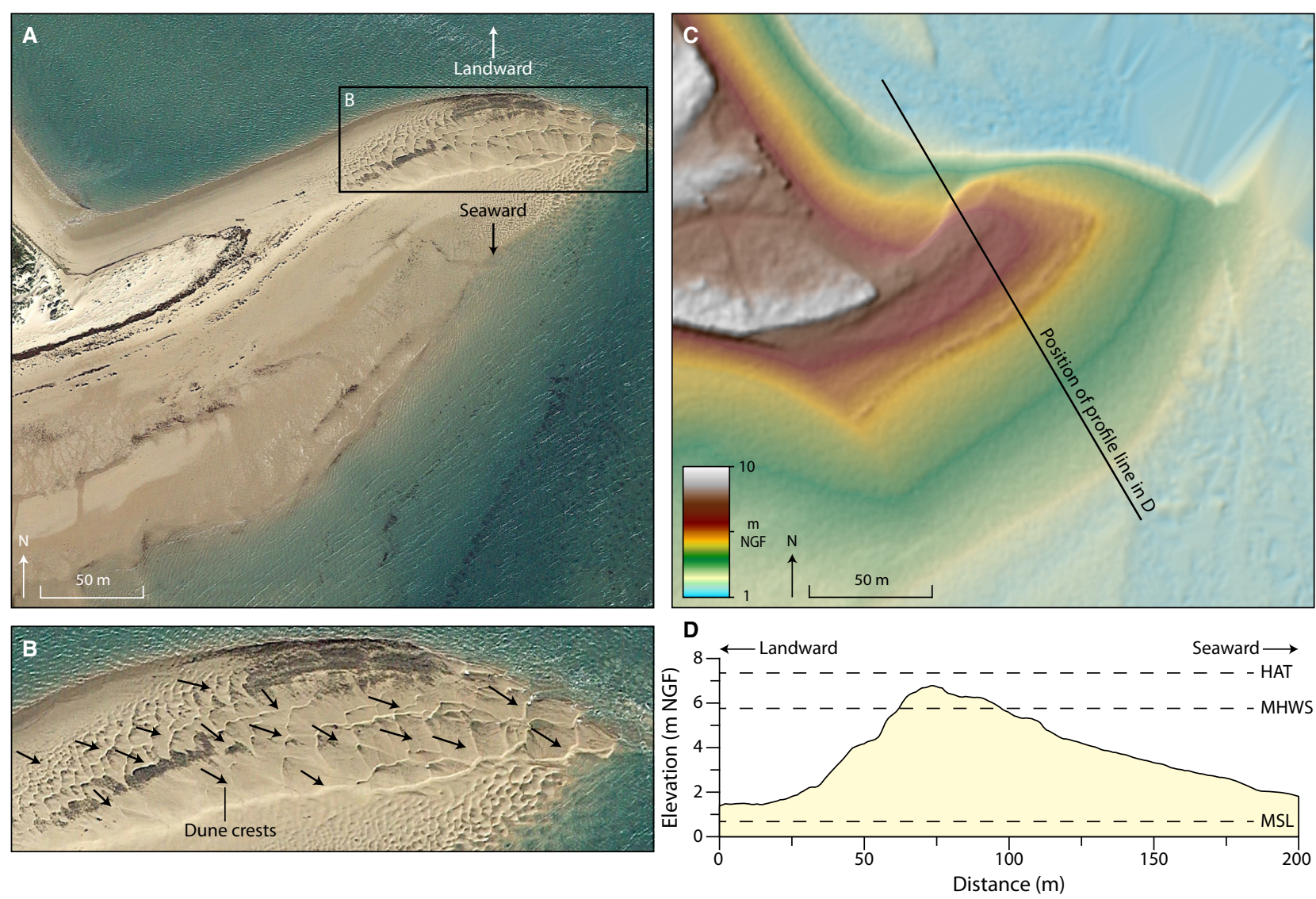

Fig. 6. The geomorphology of the recurved Pointe du Banc spit terminus. (A) Google Earth๔ satellite image recorded on 29 September 2015. The image was taken shortly after high water during which most of the spit terminus had been submerged. (B) Close-up of the spit terminus with ebb-oriented sinuous tidal dunes migrating across the spit in a seaward direction. The black arrows indicate the approximate direction of the flow that formed the dunes. (C) and (D) Digital terrain model (DTM) elevation cross-profile of the spit terminus. Note that the DTM and satellite image were recorded in two different years. HAT, highest astronomical tide; MHWS, mean high water spring; NGF, Nivellement Général de la France.

structures reaching elevations up to $7.8 \mathrm{~m}$ NGF are interpreted as aeolian dunes (Fig. 9, RU1). The landward and seaward inclined bedding suggests that the dunes grew by foreslope and lee-shadow accretion of sand that became trapped in vegetation covering the dune (Bristow et al., 2000). Seaward-merging mounded structures with inclined bedding predominantly dipping seaward from RU1 are interpreted as seaward prograding coastal dune ridges (Fig. 9, RU2). The concave-up reflections of RU3 are mainly observed in association with RU1 and are interpreted as swales between dune ridges. The high-amplitude lower-bounding reflection is interpreted as a vegetation-covered surface (Fig. 9, RU3). Layers of sand enriched in organic matter and containing roots and rootlets are interpreted as palaeosols commonly observed in aeolian deposits. They are indicative of dune stabilisation and soil formation (Clemmensen et al., 2001) (Tabel 1, CF1). The concave-up reflections of RU4 that truncate underlying deposits are interpreted as trough cut and fill deposits (Fig. 9, RU4). Similar trough-shaped bodies were interpreted by Bristow et al. (2000) as trough cross-stratification produced by windgenerated scour and fill deposits.

\section{Barrier unit}

Core facies CF2 and radar units RU5 to RU7 form the barrier spit unit: The highly continuous sigmoidal-oblique reflections of RU5, which dip up to $3^{\circ}$ towards the south-east and are arranged in packages separated by higher-amplitude bounding reflections, are interpreted as spit topsets and foresets that formed by longshore and beach drift resulting from longshore sediment transport (Nielsen et al., 1988; Nielsen \& 

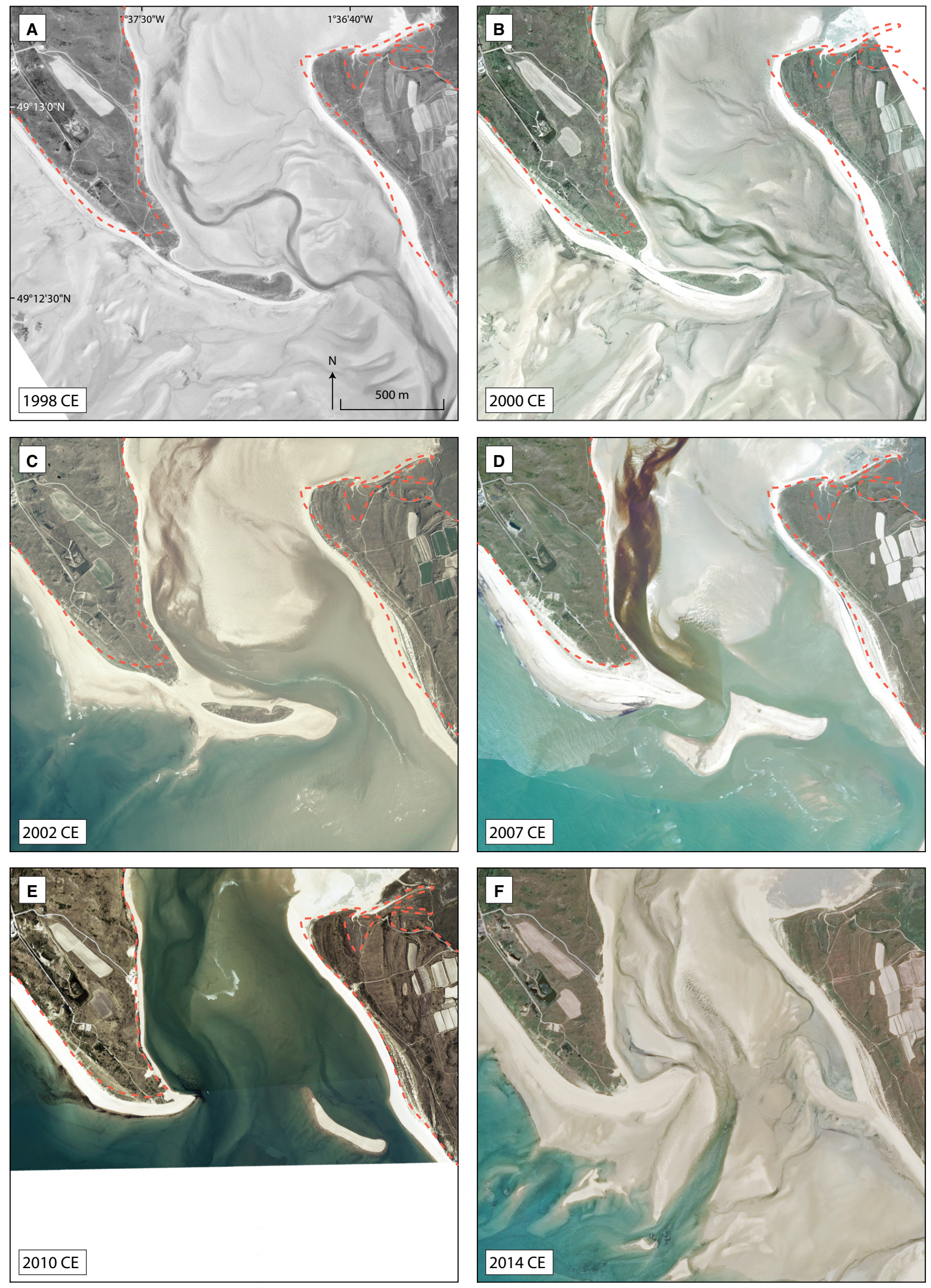

(C) 2019 The Authors. Sedimentology (C) 2019 International Association of Sedimentologists, Sedimentology, 67, 502-533 
Table 1. Core facies description and interpretation.

\begin{tabular}{|c|c|c|c|}
\hline $\begin{array}{l}\text { Core } \\
\text { facies }\end{array}$ & Description & $\begin{array}{l}\text { Elevation in } \\
\text { cores (m NGF) }\end{array}$ & $\begin{array}{l}\text { Depositional } \\
\text { environment }\end{array}$ \\
\hline CF1 & $\begin{array}{l}\text { Thickness of successions ranging from } 0.15 \text { to } 0 \cdot 80 \mathrm{~m} \text {; } \\
\text { very fine to fine-grained sand; well-sorted and well- } \\
\text { rounded; mostly without visible structures but parallel } \\
\text { laminations are occasionally observed; in situ roots and } \\
\text { rootlets are abundant; layers with parallel laminated } \\
\text { organic matter are observed; the organic matter content } \\
\text { increases towards the top }\end{array}$ & $6 \cdot 1$ to $7 \cdot 6$ & $\begin{array}{l}\text { Aeolian dune or } \\
\text { sand sheet } \\
\text { with palaeosols }\end{array}$ \\
\hline CF2 & $\begin{array}{l}\text { Thickness of successions ranging from } 2 \cdot 2 \text { to } 3 \cdot 3 \mathrm{~m} \text {; beds } \\
\text { of medium to well-sorted very fine to medium-grained } \\
\text { sand in places overlying a layer of pebbles ( } 2 \text { to } 7 \mathrm{~mm} \text { in } \\
\text { diameter), shells and shell fragments in a matrix of } \\
\text { poorly to well-sorted coarse-grained sand; base of beds } \\
\text { overlies a sharp or erosion surface; indistinct horizontal } \\
\text { and inclined parallel lamination is observed }\end{array}$ & $2 \cdot 8$ to $7 \cdot 1$ & $\begin{array}{l}\text { Spit terminus } \\
\text { with tidal dunes, } \\
\text { scour pits and swash } \\
\text { bars }\end{array}$ \\
\hline CF3 & $\begin{array}{l}\text { Thickness of successions ranging from } 1.0 \text { to } 2.4 \mathrm{~m} \text {; the } \\
\text { lowermost part of some successions overlies an erosion } \\
\text { surface and has a base of fine-grained sand with shells, } \\
\text { shell fragments and pebbles (diameters up to } 5 \mathrm{~cm} \text { ) and } \\
\text { overlies an erosion surface; beds of very fine-grained } \\
\text { sand that occasionally fine upward, base of beds is } \\
\text { sharp; the sand is indistinctly parallel-laminated }\end{array}$ & $4 \cdot 4$ to $7 \cdot 0$ & $\begin{array}{l}\text { Tidal shoal } \\
\text { without bedforms }\end{array}$ \\
\hline $\mathrm{CF} 4$ & $\begin{array}{l}\text { Thickness of successions up to } 3.4 \mathrm{~m} \text {; up to } 0.5 \mathrm{~m} \text { thick } \\
\text { beds of very fine to coarse-grained sand overlying a } \\
\text { sharp surface; some beds have a coarse base composed } \\
\text { of pebbles, shells and shell fragments in a medium to } \\
\text { coarse-grained matrix; beds are non-graded or fining } \\
\text { upward and the successions are mainly coarsening } \\
\text { upward; no visible structures }\end{array}$ & $\begin{array}{l}<1 \cdot 1 \text { to } 5 \cdot 3 \text {; } \\
\text { lower limit } \\
\text { not reached }\end{array}$ & $\begin{array}{l}\text { Tidal shoal with } \\
\text { tidal dunes }\end{array}$ \\
\hline CF5 & $\begin{array}{l}\text { Thickness of successions ranging from } 0.2 \text { to } 1.0 \mathrm{~m} \text {; } \\
\text { interbedded very fine to fine-grained well-sorted sand } \\
\text { and mud; flaser and wavy bedding characterise the } \\
\text { deposits; parallel laminated beds are observed; rich in } \\
\text { shells and shell fragments; occasionally clasts of organic } \\
\text { matter; burrows are observed; bioturbation degree is low } \\
\text { to moderate; roots are observed }\end{array}$ & $2 \cdot 5$ to 5.9 & $\begin{array}{l}\text { Heterolithic tidal } \\
\text { flat }\end{array}$ \\
\hline CF6 & $\begin{array}{l}\text { Thickness of successions up to } 0.2 \mathrm{~m} \text {; parallel-laminated } \\
\text { mud; lenticular bedding is observed; stems, leaf and } \\
\text { shell fragments are commonly observed; few burrows } \\
\text { and low degree of bioturbation }\end{array}$ & $3 \cdot 6$ to $4 \cdot 8$ & $\begin{array}{l}\text { Mudflat or salt } \\
\text { marsh }\end{array}$ \\
\hline
\end{tabular}

Johannessen, 2009; Lindhorst et al., 2010) (Fig. 9, RU5). The bounding reflections are interpreted as erosion surfaces. North-west steeply-dipping and short reflections are locally preserved within the packages. They are interpreted as foresets that formed as intertidal swash bars migrated up the large-scale spit foresets (Hine, 1979; Nielsen \& Johannessen, 2009; Robin et al., 2009b).

Radar units RU6 and RU7 are interpreted as spit terminus deposits. Unit RU6 is composed of: (i) low-angle seaward-dipping sigmoidaloblique reflections interpreted as beach and

Fig. 7. Orthorectified aerial photographs of the Pointe du Banc spit terminus evolution from 1998 to 2014 CE. After the spit terminus became detached from the spit between $2005 \mathrm{CE}$ and 2006 CE it migrated across the estuary mouth as a swash bar until it attached to the opposite shore between $2010 \mathrm{CE}$ and $2014 \mathrm{CE}$. The dashed red lines in (A) through to (E) indicate the position of the mean high water spring level in 2014 CE. This level approximately corresponds to the vegetation line. 
Fig. 8. Sedimentological core logs from the nine boreholes. Core facies (CF) referring to Table 1 are indicated to the right of the logs and the logs are colour coded according to their depositional unit (see main text). For location of the boreholes, see Fig. 3 .

shoreface clinoforms; and (ii) landward-dipping reflections with short, steeply seaward-dipping, downlapping reflections interpreted as tidal dune foresets (Dalrymple, 1984) that migrated up the landward-side of the spit terminus (Fig. 9, RU6). In the scour pits between the dunes, coarsegrained sand, pebbles and shells accumulate on an erosion surface formed by winnowing and scour of fine sediment (Allen, 1980) (Fig. 5E and F). The scour pit deposits are overlain by moderately to well-sorted very fine to medium-grained sand deposited during tidal dune migration, resulting in sand beds with a coarse, poorly sorted lag separated by master bedding surfaces (Table 1, CF2). These surfaces may be visible through enhancement by erosion from swash processes on the landward side of the spit terminus during falling tide and from rill erosion caused by runoff and water seepage from the spit terminus during low water (Fig. 5G). Distinct erosion surfaces bundle sets of foresets and master bedding into well-defined packages. Unit RU7 consists of short, steeply landward-dipping, downlapping reflections attributed to onshore migrating swash bar foresets with a height up to about $1 \mathrm{~m}$ (Fig. 9, RU7). Active storm-dominated swash bars are well-developed along the spits of the western Cotentin shore having crests up to 2 m high (Robin et al., 2009a; Levoy et al., 2013; Montreuil et al., 2014). The swash bar foresets are bundled into packages separated by reactivation surfaces that formed by wave and tideinduced erosion in the intervening periods between storms where the swash bars were inactive. Alternatively, these reactivation surfaces may have formed by wave scouring during storms (Lindhorst et al., 2008).

\section{Estuarine unit}

Core facies CF3 to CF6 and radar units RU8 to RU11 are interpreted as tide-dominated estuarine deposits. Unit RU8 is composed of medium to high-amplitude, parallel and sub-parallel reflections, which are laterally continuous up to $100 \mathrm{~m}$. The reflections are interpreted as tidal shoals, apparently without bedforms or bedforms smaller than the vertical resolution of the GPR (Figs 5A, 5B and 9, RU8). The tidal shoals consist of very fine to medium-grained, wellsorted sand with occasional muddy flaser and wavy bedding (Table 1, CF3 and CF5) (Reineck \& Wunderlich, 1968).

Unit RU9 is composed of short $(<0.4 \mathrm{~m})$, low to medium-amplitude discontinuous, reflections with an apparent dip up to $15^{\circ}$ mostly in northerly directions (Fig. 9, RU9). The corresponding sediment facies is composed of beds of very fine to coarse-grained sand with a base of pebbles, shells and coarse-grained sand often separated by erosion surfaces (Table 1, CF4). Deposits RU9 and CF4 are interpreted as prograding and accreting foresets that formed by migrating flood-dominated small-scale tidal dunes. As dunes migrated, shells, pebbles and coarse-grained sand accumulated in the tidal dune troughs, forming bounding surfaces between sets of dune foresets. The dimensions of the imaged tidal dune foresets correspond to the modern HDL estuary tidal dunes, having foresets up to $30 \mathrm{~cm}$ high (Fig. 5I).

Unit RU10 is composed of oblique-tangential reflections, which dip up to $15^{\circ}$ towards the north-east (Fig. 9, RU10). The reflections are interpreted as foresets that formed by migration of a swash bar. The preserved part of the bar is up to $200 \mathrm{~m}$ wide and $3 \mathrm{~m}$ high but, since the bedform appears to be truncated, the original height may have been greater. The primary reflections are arranged into 20 to $50 \mathrm{~m}$ wide packages separated by medium-amplitude reflections that are interpreted as erosion surfaces. The latter may have formed during tidal flow reversals and by secondary bedforms that migrated up the foresets of the swash bar.

Unit RU11 is observed in association with an exposed high-lying bedrock surface. The landward dipping reflections are therefore interpreted as washover clinoforms that grew by the accretion of sediment deposited when the rock platform was overwashed during storms or spring tides (Fig. 9, RU11). Similar landwarddipping reflectors of comparable size are described by Garrison et al. (2010) as an architectural component of a barrier. They are interpreted as washover clinoforms, contributing to the landward growth of the studied barrier.

\section{Internal architecture and geometries}

Based on their position and quality, five GPR profiles were chosen to illustrate the internal 

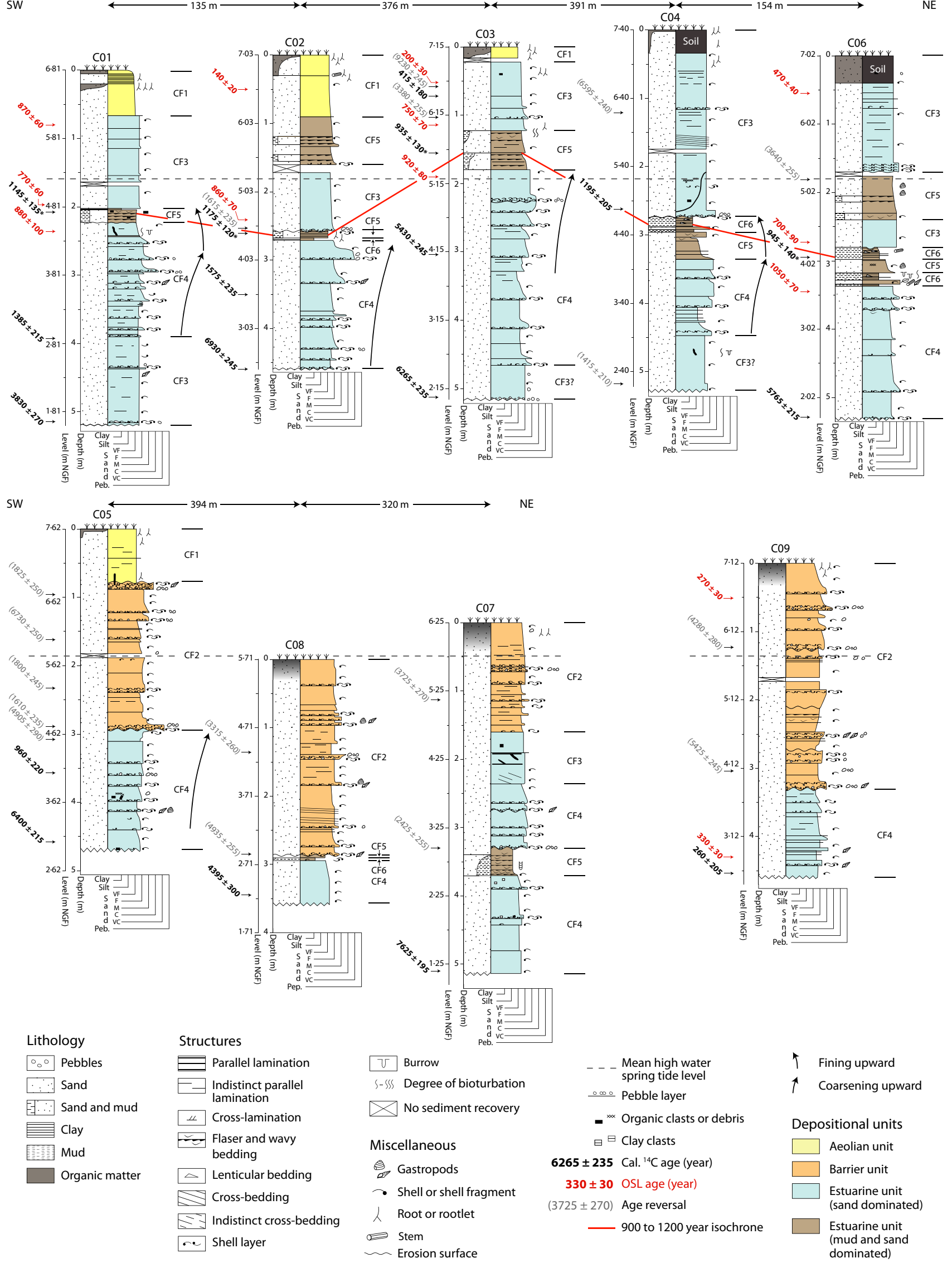

(C) 2019 The Authors. Sedimentology (C) 2019 International Association of Sedimentologists, Sedimentology, 67, 502-533 
architecture and geometries of the barrier system. The five profiles are shown in Figs 10 to 13 and their locations in Fig. 3.

\section{Profile $A-A^{\prime}$}

The $1300 \mathrm{~m}$ long south-west/north-east-oriented profile $\mathrm{A}-\mathrm{A}^{\prime}$ runs from the seaward facing coast to the back-barrier coast of the modern PDB spit (Fig. 10). Below an altitude ranging around 4 to $5 \mathrm{~m} \mathrm{NGF}$, the profile is mainly composed of estuarine deposits, represented by RU8, RU9, RU10 and RU11 (Fig. 9). About $25 \mathrm{~m}$ from the south-west end of the profile, at a depth of $c a 3.5 \mathrm{~m} \mathrm{NGF}$, several diffraction hyperbolas are observed and interpreted to image the bedrock surface. Between $25 \mathrm{~m}$ and $130 \mathrm{~m}$, directly south-west of the bedrock, landward dipping reflections of RU11 are observed which are interpreted as clinoforms that formed during an overwash event of the bedrock. From 130 to $625 \mathrm{~m}$ and from about 775 to $1225 \mathrm{~m}$ at depths between $2.0 \mathrm{~m}$ and $3.5 \mathrm{~m}$ NGF the profile is composed of short, north-east-dipping, discontinuous reflections of RU9 and by continuous, horizontal reflections of RU8, which are interpreted as tidal shoals with and without bedforms (Fig. 9). From 625 to $775 \mathrm{~m}$, at depths from 3.1 to $6.3 \mathrm{~m} \mathrm{NGF}$,

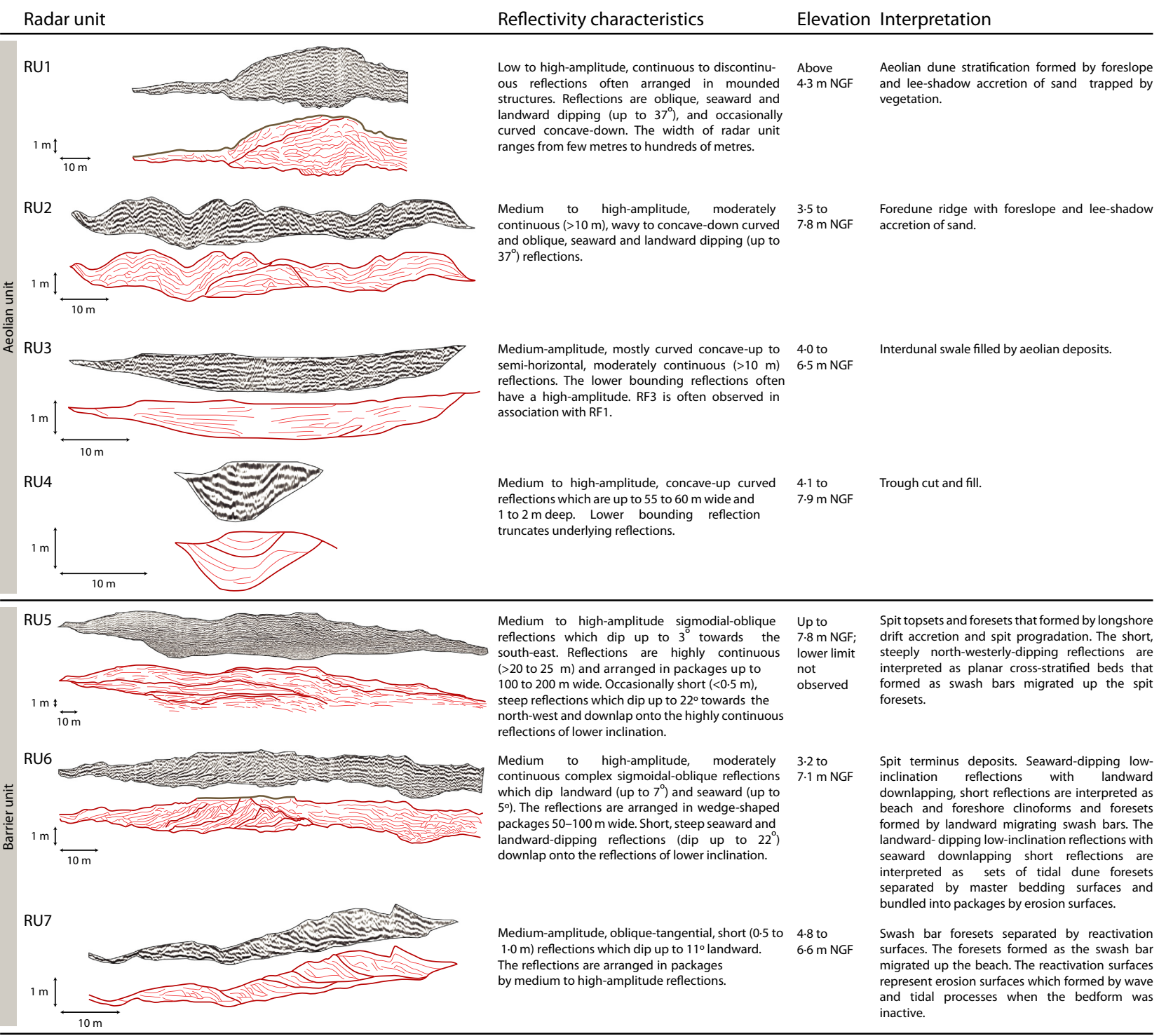

Fig. 9. Radar unit characteristics and geological interpretation. Terminology of reflection characteristics is based on Neal (2004). Directions of dips are apparent measures and inclinations are given without vertical exaggeration. The amplitudes are all relative due to corrections applied during processing. 


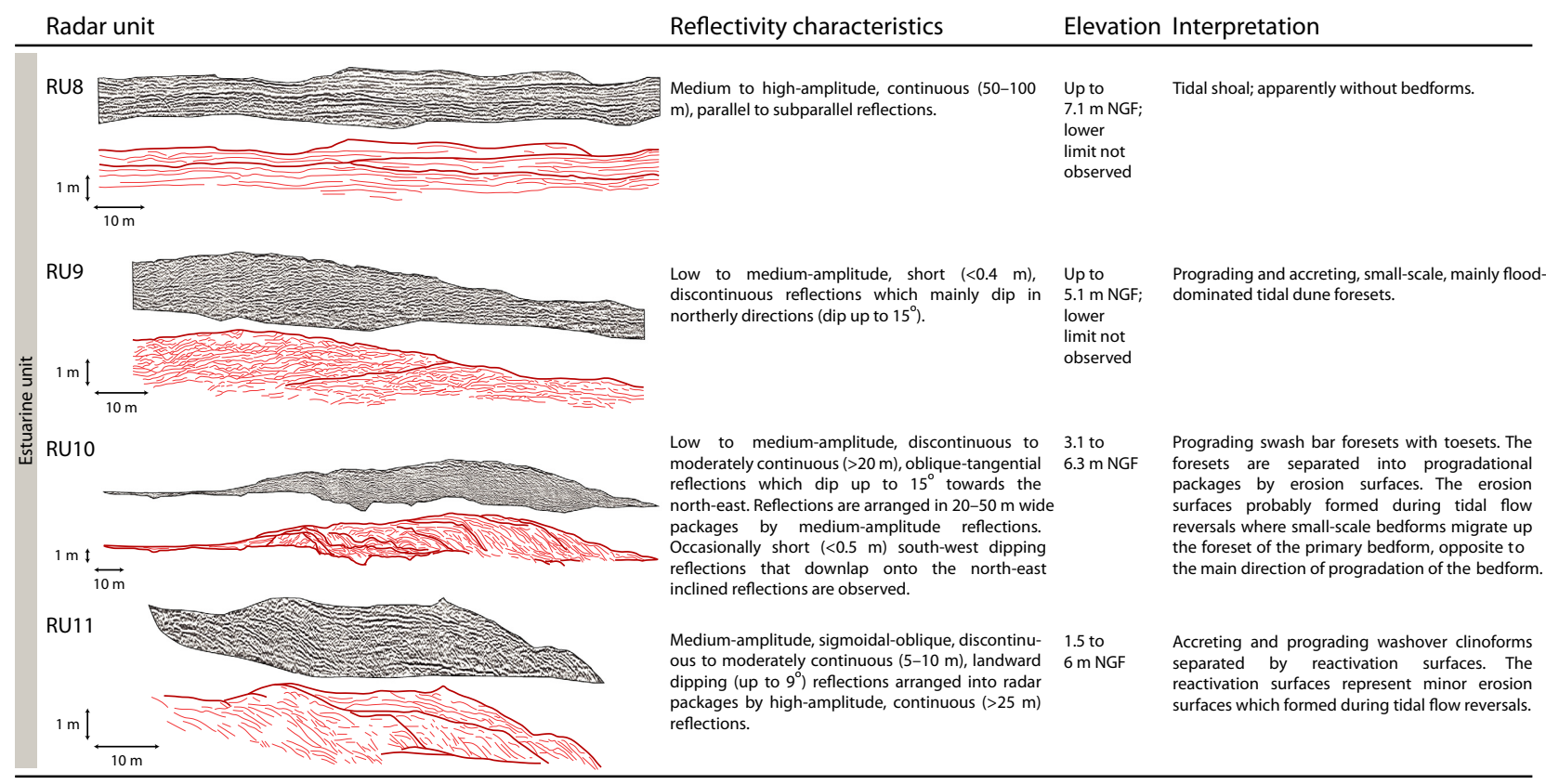

Fig. 9. Continued.

large-scale north-east-dipping reflections of RU10 are observed. These reflections are interpreted as foresets deposited by a landward migrating swash bar (Fig. 9).

The upper part of the profile, above 4 to $5 \mathrm{~m} \mathrm{NGF}$, is composed of estuarine, barrier and aeolian deposits. South-west and northeast-dipping reflections of RU6 overlain by reflections of RU1, RU2 and RU3 are observed from 0 to $225 \mathrm{~m}$, from 900 to $1050 \mathrm{~m}$ and from 1200 to $1300 \mathrm{~m}$, respectively. These reflections are interpreted as spit terminus deposits overlain by aeolian deposits (Fig. 9). From 225 to $900 \mathrm{~m}$ and from 1050 to $1200 \mathrm{~m}$ the profile is composed of short, horizontal reflections of RU8 interpreted as tidal shoal sediments. A low to medium-amplitude, discontinuous reflection extending from 0 to $1250 \mathrm{~m}$ separates the lower estuarine deposits from the upper barrier, estuarine and aeolian deposits (Fig. 10, solid black line). This reflection approximately corresponds to the beds of fine-grained sand and mud (CF4 and CF5) observed in the cores C01, C02, C03, C04 and C06, which are interpreted as heterolithic tidal flat, mudflat or salt marsh deposits.

\section{Profile $B-B^{\prime}$}

The north-south-oriented profile $B-\mathrm{B}^{\prime}$ is $490 \mathrm{~m}$ long and has a maximum penetration depth down to $c a 2.5 \mathrm{~m}$ NGF (Fig. 11). The lower interval of the profile is characterised by short, discontinuous, northward or southward-dipping reflections of RU9 and semi-continuous, horizontal to sub-horizontal reflections of RU8 (Fig. 9). These deposits are interpreted as tidal shoal deposits of the estuarine unit. From 0 to $150 \mathrm{~m}$, at depths between $3.5 \mathrm{~m}$ and $7.0 \mathrm{~m}$ NGF, the profile is composed of northward and southward-dipping reflections of RU6, which are interpreted as spit terminus deposits of the barrier unit (Fig. 9). Aeolian deposits of RU1 overlie RU6. Between $150 \mathrm{~m}$ and $490 \mathrm{~m}$, the profile is composed of parallel to sub-parallel, horizontal reflections of RU8 and sub-horizontal to southward-dipping reflections of RU8 and RU9. From RU6 in the northern part of the profile to about $325 \mathrm{~m}$, reflections of RU8 dip southward and between $450 \mathrm{~m}$ and $475 \mathrm{~m}$ reflections of RU9 dip northward.

\section{Profile $C-C^{\prime}$}

The coast-parallel profile $\mathrm{C}-\mathrm{C}^{\prime}$ is about $575 \mathrm{~m}$ long and has a maximum penetration depth down to $c a 2.5 \mathrm{~m} \mathrm{NGF} \mathrm{(Fig.} \mathrm{12).} \mathrm{The} \mathrm{lower} \mathrm{part}$ of the profile up to about $6 \mathrm{~m}$ NGF is characterised by medium to high-amplitude, semi-continuous to continuous, horizontal to south-eastdipping reflections of RU5, which are interpreted as barrier spit topsets and foresets that formed by downdrift clinoformal spit and beach progradation (Fig. 9). The reflections are 
arranged into bounding bodies up to $200 \mathrm{~m}$ wide separated by erosion surfaces that may have formed by lateral displacement of the tidal channel occupying the estuary mouth. Alternatively, the surfaces formed during periods of spit stabilisation. The presence of erosion surfaces suggests that spit progradation was discontinuous. Short $(<0.5 \mathrm{~m})$ north-west-inclined reflections with a maximum apparent dip up to $22^{\circ}$ and downlapping the spit foresets (for example, from 240 to $270 \mathrm{~m}$ between $5.3 \mathrm{~m}$ and $6.9 \mathrm{~m}$ NGF) are interpreted as swash bars or flooddominated tidal dunes that migrated up the spit. Aeolian deposits of RU1 and RU3 overlie the barrier-spit deposits.

\section{Profile $D-D^{\prime}$}

The $c a 175$ m long profile D-D' has a maximum penetration depth of $2 \mathrm{~m}$ NGF (Fig. 13). The lower part of the profile up to about 4.5 to $5.0 \mathrm{~m}$ NGF is composed of short $(0.2$ to $0.4 \mathrm{~m})$ reflections of RU9 dipping, up to $15^{\circ}$, mostly towards the north. These reflections are interpreted as predominantly flood-dominated tidal-dune foresets of the estuarine unit (Fig. 9). Between $0 \mathrm{~m}$ and $75 \mathrm{~m}$, RU9 is overlain by semi-continuous, northward-dipping reflections of RU6 interpreted as tidal dune master bedding, which is bundled into packages by steeply inclined reflections interpreted as erosion surfaces. Short $(<0.5 \mathrm{~m})$, steeply southward-dipping (up to $22^{\circ}$ ) reflections downlapping to the master bedding are interpreted as tidal dune foresets. From 75 to $125 \mathrm{~m}$, RU9 is overlain by southward-dipping reflections of RU6 interpreted as beach and shoreface clinoforms. Short $(<0.5 \mathrm{~m})$, steeply northward-dipping reflections downlapping the beach and shoreface clinoforms are interpreted as landward-migrating swash bars. Aeolian deposits of RU1 overlie RU6 (Fig. 9).

\section{Profile $E-E^{\prime}$}

This south-west/north-east profile perpendicular to the coast is located about $75 \mathrm{~m}$ south-east of profile $\mathrm{C}-\mathrm{C}^{\prime}$ (Fig. 3). The lower 0.5 to $1.0 \mathrm{~m}$ of the profile is composed of short discontinuous $(<0.4 \mathrm{~m})$ reflections of RU9 which have an apparent dip towards the north-east (Figs 9 and 13). These reflections are interpreted as flooddominated tidal dune foresets. The upper $c a$ $3.5 \mathrm{~m}$ of the profile is composed of semi-continuous south-west-dipping reflections of RU6 interpreted as shoreface clinoforms. Unit RU6 envelops RU7 that is composed of oblique-tangential, 0.5 to $1.0 \mathrm{~m}$ long reflections dipping up to $11^{\circ}$ towards the north-east (landward) and bundled into packages separated by medium to high-amplitude reflectors (Fig. 9). These reflections are interpreted as swash bar foresets or flood-dominated tidal dune foresets that migrate up the shoreface and are separated by reactivation surfaces.

\section{Absolute chronology and sediment accumulation rates}

Radiocarbon and OSL ages range from 7600 to 140 years (Tables 2 and 3). The ${ }^{14} \mathrm{C}$ chronology contains several age reversals that were omitted from the chronology of the barrier spit system (Table 2). Most of the age reversals are observed in CF2 of the barrier spit unit (Table 1) suggesting that the spit formation was associated with substantial erosional processes and sediment reworking. The ages from the nine cores are plotted in age versus depth diagrams together with a relative sea-level curve (Lambeck, 1997; Fig. 14). The plots show that the cored sediments were deposited at depths between $1.1 \mathrm{~m}$ and $6.6 \mathrm{~m} \mathrm{NGF}$, corresponding to between about $2 \mathrm{~m}$ and $6 \mathrm{~m}$ above mean sea level at the time of deposition (Fig. 14). The lower part of all cores is composed of estuarine deposits of CF3 and CF4 which were deposited about 7600 to 1000 years ago, with the exception of C09 where the deposits accumulated about 330 years ago (Figs 8 and 14). Estuarine deposits in cores C01, C02, C03 and C06 are overlain by heterolithic tidal flat, mudflat or salt marsh sediments of CF5 and CF6, and estuarine deposits of CF3 which were deposited at about 1200 to 900 years ago and about 900 to 700 years ago, respectively (Figs 8 and 14). The upper parts of the cores C02, C03, C04 and C09 are composed of estuarine, barrier or aeolian deposits of CF1,

Fig. 10. Ground penetrating radar (GPR) profile $A-A^{\prime}$, which runs from the seaward coast to the back-barrier coast across the barrier spit. Three depositional barrier units overlain by aeolian sand are observed in the profile. The bold black line marks the boundary between older estuarine deposits and younger estuarine and barrier deposits. In the cores this boundary corresponds to core facies CF5 or CF6, interpreted as heterolithic tidal flat and mudflat or saltmarsh, respectively. Note that the GPR profile is cut off at $10 \mathrm{~m}$ Nivellement Général de la France (NGF) to enhance the visualisation of the marine deposits. 


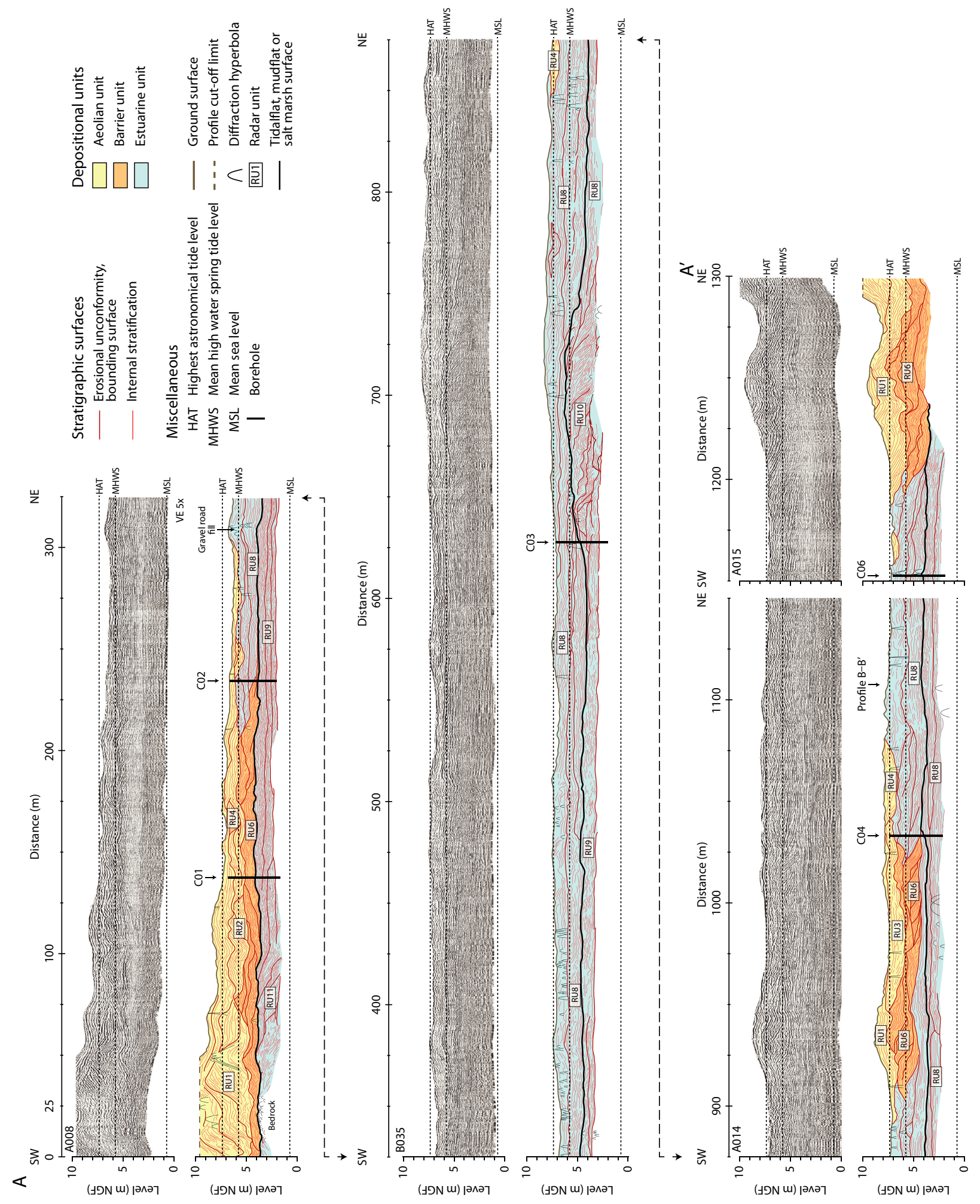



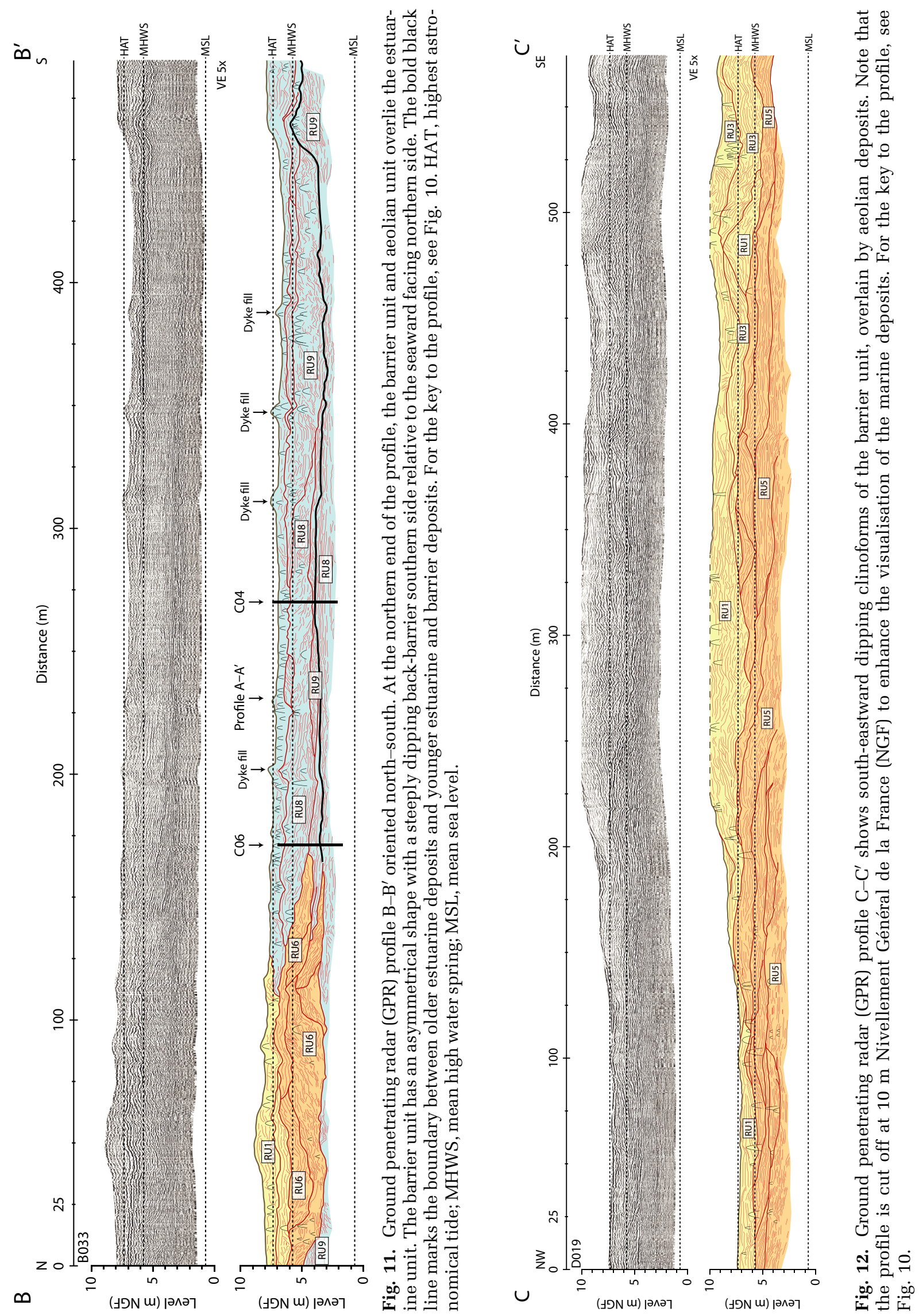

(C) 2019 The Authors. Sedimentology (C) 2019 International Association of Sedimentologists, Sedimentology, 67, 502-533 

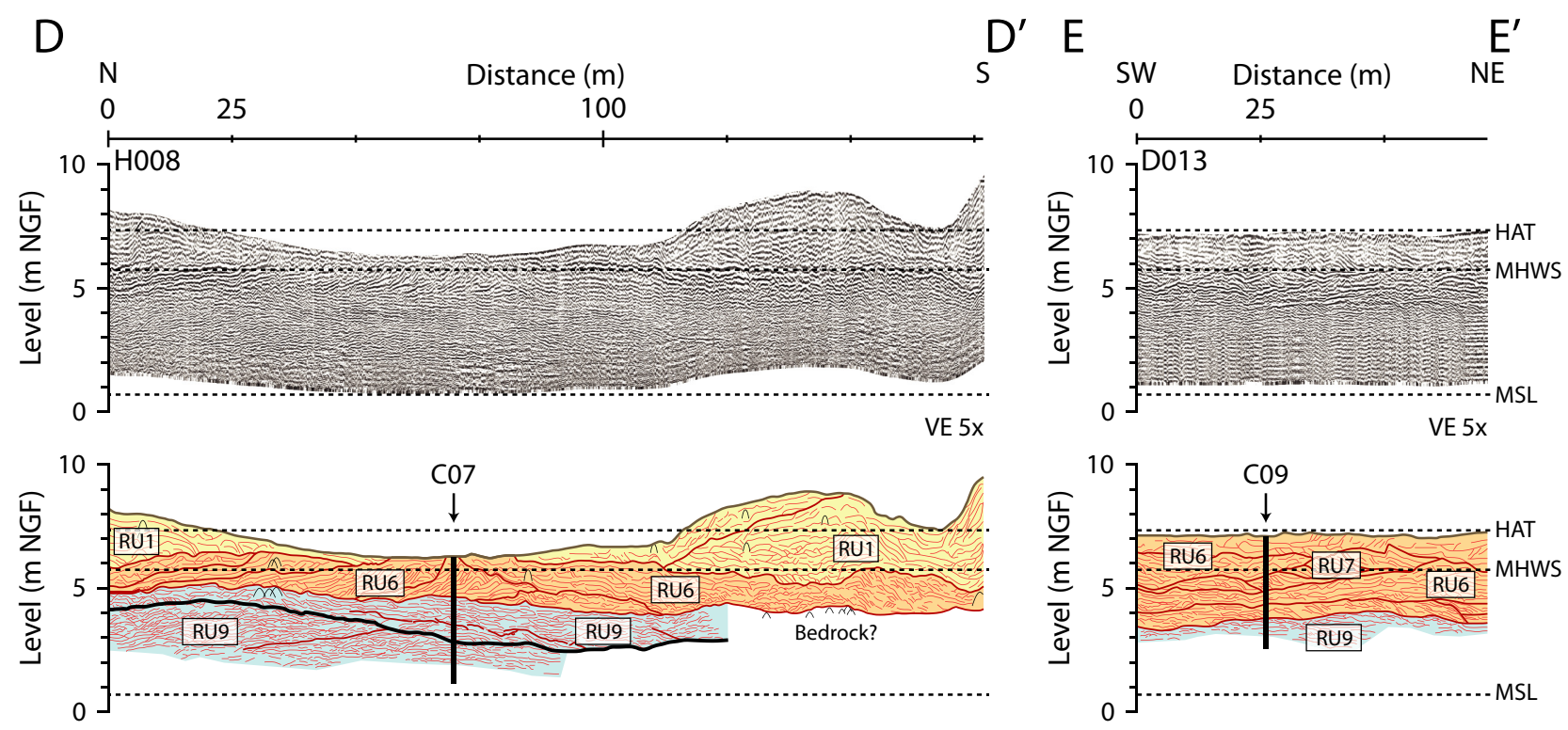

Fig. 13. Ground penetrating radar (GPR) profiles D-D' and $E-E^{\prime}$. The bold black line in profile D-D marks the boundary between older estuarine deposits and younger estuarine and barrier deposits. For the key to the profiles, see Fig. 10. HAT, highest astronomical tide; MHWS, mean high water spring; MSL, mean sea level.

CF2 or CF3 which formed about 500 to 140 years ago (Figs 8 and 14).

The absolute chronology shows that vertical sediment accretion occurred at variable rates with a significant apparent increase after 1400 years ago, resulting in approximately $3 \mathrm{~m}$ of vertical sediment accumulation in about 800 years (Fig. 15). From about 600 years ago to today the effective sediment accretion rate was less than $0.1 \mathrm{~mm} \mathrm{year}^{-1}$, except in core C09 where the rate was very high resulting in a $c a$ $4.5 \mathrm{~m}$ thick succession with no apparent difference in age from bottom to top of the cored sequence (Figs 8 and 14).

\section{DISCUSSION}

\section{Long-term evolution of the Pointe du Banc barrier system}

Integration of core, GPR and chronological data allows reconstruction of the temporal and spatial evolution of the study area since the mid-Holocene. The overall depositional history of the system occurred in roughly three stages (Fig. 16).

Prior to 1000 years BP the mainland shoreline was situated 2 to $3 \mathrm{~km}$ eastward of the presentday shoreline. The study area was a large estuarine embayment, probably protected on the seaward side by a bedrock platform. Tidal flats
(Table 1; CF3 to CF4 and Fig. 9; RU8 to RU9) developed in this sheltered depositional environment (Fig. 16A). The presence of tidal dunes suggests that the embayment was influenced by tidal processes but, along the landward-facing side of the bedrock platform, washover fans (Fig. 9, RU11) were deposited showing the importance of wave processes in the evolution of the study site. No direct sedimentary evidence of coastal barriers is found in the study area before $c a 1000$ years ago. However, the form and dimensions of the swash bar (Fig. 9, RU10) observed in the GPR profile A-A' at about 625 to $750 \mathrm{~m}$ (Fig. 10) are comparable to those of a modern swash bar which formed by detachment of the barrier spit terminus (Fig. 7). Therefore, the authors speculate that barrier spits have formed prior to 1000 years ago northward or westward of the study site. This is inferred from data and conclusions on the late Holocene evolution of the wave-dominated margin of the bay of Mont Saint-Michel, located about $50 \mathrm{~km}$ south of the PDB barrier (Billeaud et al., 2007, 2009). Due to the fact that in the PDB area the geological substrate is very shallow and crops out at many places (Fig. 1D), these early spits were probably anchored on the protruding bedrock (Fig. 16A). In this position, little or no accommodation space resulted in a poorly developed barrier and shoreface morphology (Cooper et al., 2012). According to available ${ }^{14} \mathrm{C}$ age data, 
Table 2. Summary of ${ }^{14} \mathrm{C}$ data. The ${ }^{14} \mathrm{C}$ ages are calibrated with CALIB v. 5.0.2 using the MARINE13 or NH atmosphere Mixed Marine calibration curves. The calibrated ages are relative to $1950 \mathrm{CE}$. Ages in parentheses are age reversals.

\begin{tabular}{|c|c|c|c|c|c|c|c|c|}
\hline Core & Sample ID & $\begin{array}{l}\text { Laboratory } \\
\text { ID }\end{array}$ & $\begin{array}{l}\text { Dated } \\
\text { material }\end{array}$ & $\begin{array}{l}\text { Calibration } \\
\text { curve }\end{array}$ & $\begin{array}{l}\text { Sample } \\
\text { depth } \\
\text { (m below } \\
\text { surface) }\end{array}$ & $\begin{array}{l}\text { Level } \\
(\mathrm{m} \\
\mathrm{NGF})\end{array}$ & ${ }^{14} \mathrm{C}$ age $(\mathrm{yr})$ & $\begin{array}{l}\text { Calibrated } \\
{ }^{14} \mathrm{C} \text { age (cal. } \\
\text { year BP, } 2 \sigma \\
\text { interval) }\end{array}$ \\
\hline \multirow[t]{3}{*}{$\mathrm{C} 01$} & STG_C01_TR2_36 & Poz-61510 & Organic matter & Mixed NH & $2 \cdot 08$ & $4 \cdot 73$ & $1365 \pm 30$ & 1165 to 725 \\
\hline & STG_C01_TR4_24 & Poz-61007 & Marine shell & Marine & $3 \cdot 98$ & $2 \cdot 83$ & $1825 \pm 30$ & 1640 to 1215 \\
\hline & STG_C01_TR4_146 & Poz-61008 & Marine shell & Marine & $5 \cdot 20$ & $1 \cdot 61$ & $3840 \pm 30$ & 4105 to 3565 \\
\hline \multirow[t]{4}{*}{ C02 } & STG_C02_TR2_81 & Poz-61009 & Marine shell & Marine & $2 \cdot 52$ & $4 \cdot 51$ & $2030 \pm 30$ & 1865 to 1390 \\
\hline & STG_C02_TR2_89 & Poz-61511 & Organic matter & Mixed NH & $2 \cdot 60$ & $4 \cdot 43$ & $1395 \pm 30$ & 1195 to 750 \\
\hline & STG_C02_TR3_37 & Poz-61010 & Marine shell & Marine & $3 \cdot 50$ & $3 \cdot 53$ & $1995 \pm 30$ & 1825 to 1355 \\
\hline & STG_C02_TR3_146 & Poz-61011 & Marine shell & Marine & $4 \cdot 59$ & $2 \cdot 44$ & $6415 \pm 35$ & 7175 to 6680 \\
\hline \multirow[t]{6}{*}{ C03 } & STG_C03_TR2_36 & Poz-65864 & Marine shell & Marine & $0 \cdot 58$ & $6 \cdot 57$ & $8540 \pm 50$ & 9455 to 8970 \\
\hline & STG_C03_TR2_50 & Poz-66085 & Organic matter & Marine & $0 \cdot 72$ & $6 \cdot 43$ & $725 \pm 30$ & 545 to 185 \\
\hline & STG_C03_TR2_81 & Poz-65865 & Marine shell & Marine & $1 \cdot 03$ & $6 \cdot 12$ & $3480 \pm 30$ & 3640 to 3135 \\
\hline & STG_C03_TR2_133 & Poz-61513 & Organic matter & Mixed NH & $1 \cdot 55$ & $5 \cdot 60$ & $1200 \pm 30$ & 980 to 605 \\
\hline & STG_C03_TR3_124 & Poz-61012 & Marine shell & Marine & $3 \cdot 04$ & $4 \cdot 11$ & $5025 \pm 30$ & 5615 to 5125 \\
\hline & STG_C03_TR4_147 & Poz-61013 & Marine shell & Marine & $5 \cdot 13$ & $2 \cdot 02$ & $5810 \pm 35$ & 6465 to 5995 \\
\hline \multirow[t]{3}{*}{ C04 } & STG_C04_TR1_121 & Poz-61076 & Marine shell & Marine & $1 \cdot 21$ & $6 \cdot 19$ & $6115 \pm 35$ & 6820 to 6340 \\
\hline & STG_C04_TR2_82 & Poz-61077 & Marine shell & Marine & $2 \cdot 62$ & $4 \cdot 78$ & $1605 \pm 30$ & 1370 to 960 \\
\hline & STG_C04_TR3_140 & Poz-61078 & Marine shell & Marine & $5 \cdot 18$ & $2 \cdot 22$ & $1860 \pm 30$ & 1680 to 1255 \\
\hline \multirow[t]{7}{*}{ C05 } & STG_C05_TR1_96 & Poz-65867 & Marine shell & Marine & 0.96 & $6 \cdot 66$ & $2195 \pm 30$ & 2070 to 1570 \\
\hline & STG_C05_TR1_162 & Poz-61079 & Marine shell & Marine & $1 \cdot 62$ & $6 \cdot 00$ & $6255 \pm 30$ & 6985 to 6485 \\
\hline & STG_C05_TR2_45 & Poz-65868 & Marine shell & Marine & $2 \cdot 33$ & $5 \cdot 29$ & $2165 \pm 30$ & 2030 to 1540 \\
\hline & STG_C05_TR2_101 & Poz-65869 & Marine shell & Marine & $2 \cdot 89$ & $4 \cdot 73$ & $2025 \pm 30$ & 1860 to 1385 \\
\hline & STG_C05_TR2_120 & Poz-65870 & Marine shell & Marine & $3 \cdot 08$ & $4 \cdot 54$ & $4670 \pm 40$ & 5270 to 4690 \\
\hline & STG_C05_TR3_37 & Poz-61080 & Marine shell & Marine & $3 \cdot 57$ & $4 \cdot 05$ & $1400 \pm 30$ & 1205 to 7600 \\
\hline & STG_C05_TR3_138 & Poz-61081 & Marine shell & Marine & $4 \cdot 58$ & $3 \cdot 04$ & $5970 \pm 30$ & 6645 to 6215 \\
\hline \multirow[t]{3}{*}{ C06 } & STG_C06_TR2_10 & Poz-61082 & Marine shell & Marine & $1 \cdot 81$ & $5 \cdot 21$ & $3700 \pm 30$ & 3910 to 3400 \\
\hline & STG_C06_TR3_64 & Poz-61514 & Organic matter & Mixed NH & $2 \cdot 95$ & $4 \cdot 07$ & $1215 \pm 30$ & 995 to 620 \\
\hline & STG_C06_TR4_148 & Poz-61084 & Marine shell & Marine & $5 \cdot 29$ & $1 \cdot 73$ & $5385 \pm 30$ & 5995 to 5570 \\
\hline \multirow[t]{3}{*}{$\mathrm{C} 07$} & STG_C07_TR1_113 & Poz-61085 & Marine shell & Marine & $1 \cdot 19$ & $5 \cdot 06$ & $3770 \pm 30$ & 4010 to 3470 \\
\hline & STG_C07_TR3_119 & Poz-61086 & Marine shell & Marine & $3 \cdot 36$ & $2 \cdot 89$ & $2705 \pm 30$ & 2715 to 2210 \\
\hline & STG_C07_TR4_149 & Poz-61087 & Marine shell & Marine & $5 \cdot 16$ & $1 \cdot 09$ & $7130 \pm 40$ & 7835 to 7440 \\
\hline \multirow[t]{3}{*}{ C08 } & STG_C08_TR1_136 & Poz-61088 & Marine shell & Marine & $1 \cdot 36$ & $4 \cdot 35$ & $3395 \pm 30$ & 3540 to 3020 \\
\hline & STG_C08_TR2_117 & Poz-61089 & Marine shell & Marine & $2 \cdot 91$ & $2 \cdot 80$ & $4680 \pm 30$ & 5270 to 4765 \\
\hline & STG_C08_TR2_177 & Poz-61090 & Marine shell & Marine & $3 \cdot 51$ & $2 \cdot 20$ & $4245 \pm 30$ & 4685 to 4090 \\
\hline \multirow[t]{3}{*}{ C09 } & STG_C09_TR1_123 & Poz-61093 & Marine shell & Marine & $1 \cdot 23$ & $5 \cdot 89$ & $4165 \pm 30$ & 4540 to 3975 \\
\hline & STG_C09_TR2_131 & Poz-61094 & Marine shell & Marine & $3 \cdot 04$ & $4 \cdot 08$ & $5015 \pm 35$ & 5605 to 5110 \\
\hline & STG_C09_TR3_144 & Poz-61095 & Marine shell & Marine & $4 \cdot 54$ & $2 \cdot 58$ & $570 \pm 30$ & 415 to 1 \\
\hline
\end{tabular}

the average accretion rate of the tidal flat before 1000 years вр was $\quad c a \quad 0.5 \mathrm{~mm} \mathrm{year}^{-1}$, which approximately corresponded to or was slightly less than the contemporary RSL rise (Lambeck, 1997; Goslin et al., 2015). Accumulation was thus limited due to wave-process and tidal-process sediment dispersion in a reduced accommodation space (Fig. 15).

At about 1000 years BP, upward-coarsening successions of sandy tidal shoal deposits (Table 1, CF4) were overlain by fining-upward successions of heterolithic and fine-grained salt marsh or mudflat deposits (Fig. 8). The coarsening-upward deposits may suggest that accommodation space gradually decreased, probably due to an increase in sediment accumulation that reached up to $c a 4 \mathrm{~mm}_{\text {year }}^{-1}$ (Figs 15 and 16B). The increase may have been caused by landward and upward migration of the rock-bound barriers situated west of the study area. Overwash processes dispersed sediment into the back-barrier basin where it was reworked by tidal currents 


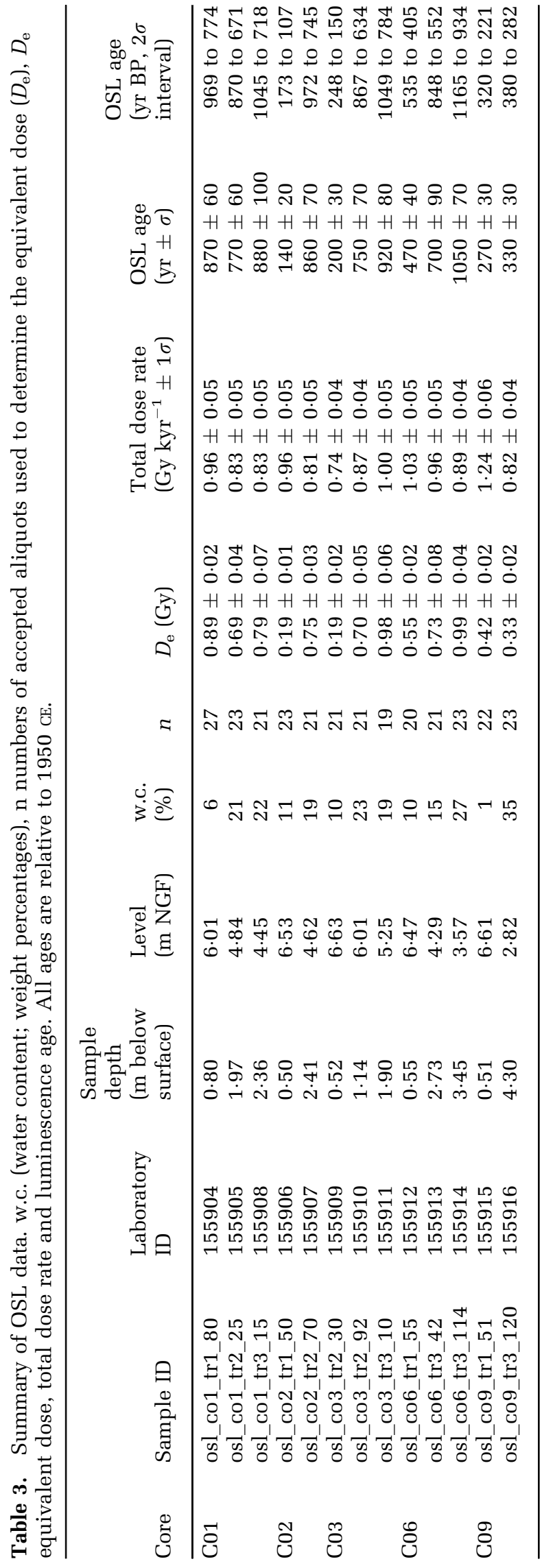

into accreting sandy tidal shoals. A significant amount of sand was probably transported into the back-barrier basin by flood-tidal processes through the tidal inlet. The tidal shoal accretion was progressively followed by the development of mudflats and salt marshes. (Table 1; CF6). These deposits formed a semi-isochronous layer with an age between 1200 years BP and 900 years вP, which marks the transition from an open tidal bay environment to a more sheltered estuarine or lagoonal environment. Alternatively, this layer was formed in response to the protection afforded by the formation of the landward prograding barrier island.

In the northern part of the study area (Fig. 8; $\mathrm{C01}, \mathrm{C02}$, C03, C04 and C06) the fine-grained mudflat and salt marsh deposits became overlain by sandy estuarine tidal shoal deposits (Table 1; CF3) 900 to 700 years ago. These deposits accumulated in a topographic low, interpreted as an indentation of the main back-barrier basin, here termed lagoon, bounded by aeolian-covered barrier ridges to the west, north and south (Figs 10, 11 and 16C). Tidal shoal sedimentation continued in the lagoon until about 200 years ago, and about 140 years ago aeolian sediments (Table 1; CF1) accumulated in the lagoon. The effective sediment accumulation rate in the lagoon was initially rapid ( $c a 4 \mathrm{~mm} \mathrm{year}^{-1}$ ) but decreased to $c a \quad 0 \cdot 1 \mathrm{~mm} \mathrm{year}^{-1}$ about 600 years ago. South of the lagoon, sandy deposits progressively accumulated in barrier and aeolian dune ridges (Fig. 9, RU1 and RU2), causing the barrier spit to grow southward. The growth may also have been enhanced by the progressive filling of the lagoon and concurrent decrease of the tidal prism. The youngest dated barrier sediments were deposited at the C09 core site approximately 300 years ago (Fig. 8). The last approximately 350 years of barrier evolution can be reconstructed from historical maps shown in Fig. 17. The first historical map record of the PDB spit is from $1670 \mathrm{CE}$ (Fig. 17A). This map shows a long narrow spit with an aeolian foredune ridge that partly encloses a small lagoon. In the period between the maps from 1764 and 1834 to $1839 \mathrm{CE}$, the size of the lagoon gradually decreased and the barrier retreated landward (Fig. 17B and C), the spit almost attaining its present-day form.

\section{Depositional dynamics of the spit terminus and comparison with existing barrier spit models}

A sedimentological model of the hypertidal PDB spit terminus depositional dynamics and 

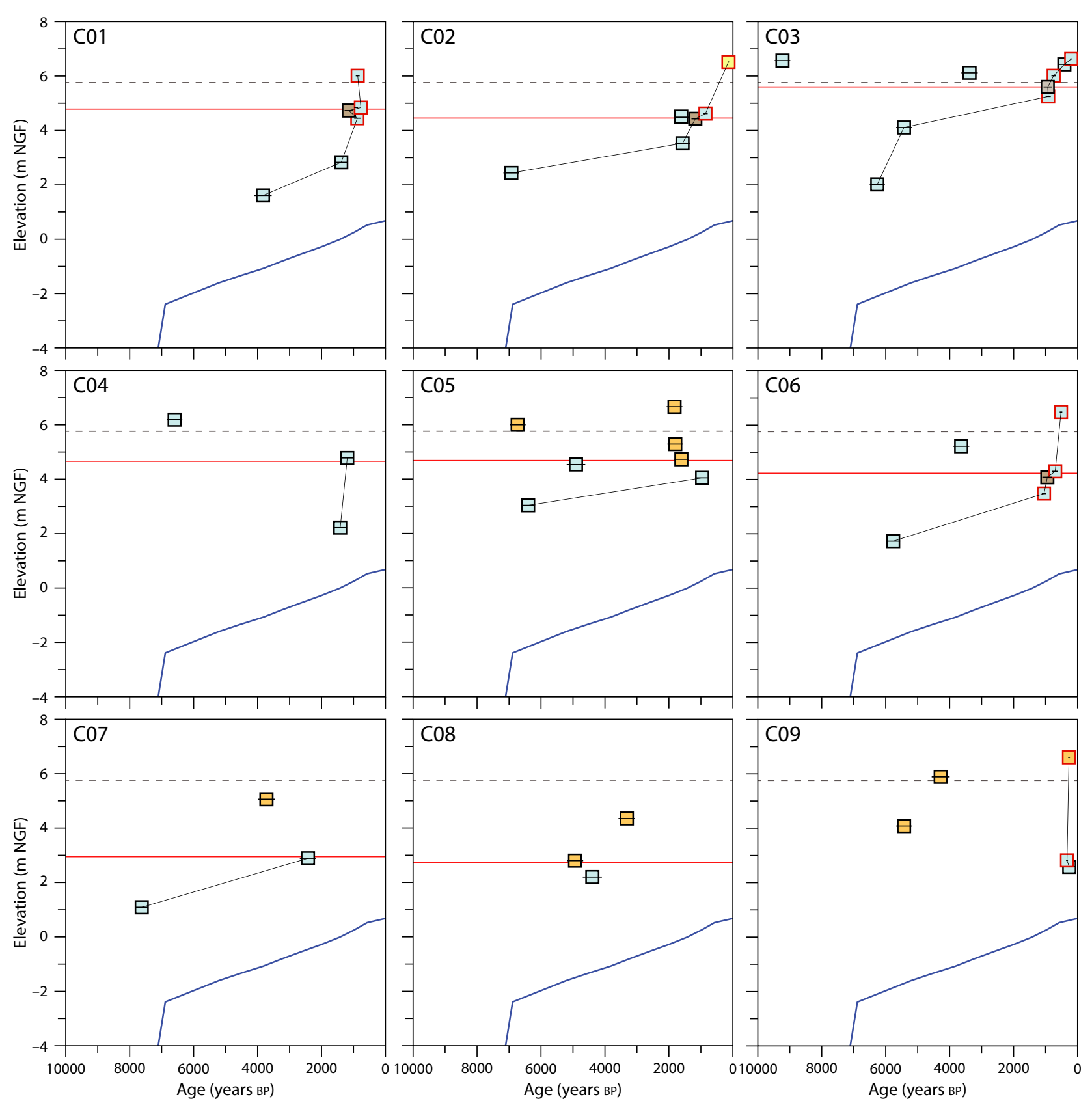

Depositional unit
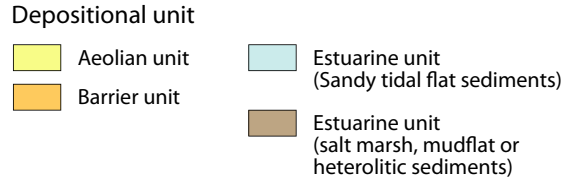

Miscellaneous

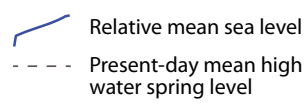

Upper level of salt marsh, mudflat and heterolitic deposits or lower level of barrier spit deposits

$\boxminus{ }^{14} \mathrm{C}$ age $\boxminus$ OSL age

Fig. 14. Age versus depth diagrams illustrating the temporal changes in depositional elevations and depositional environments relative to the RMSL curve from Lambeck (1997). For cores C01 to C08 the upper level of salt marsh deposits or the lower level of barrier spit deposits are marked by a solid horizontal red line. The solid black line connects non-inverted ages. NGF, Nivellement Général de la France.

architecture is presented in Fig. 18. Formation of the spit terminus was controlled by a combination of wave, tidal and aeolian sediment transport processes. Like spits located in wavedominated environments, the main process of spit elongation is governed by wave-induced net 


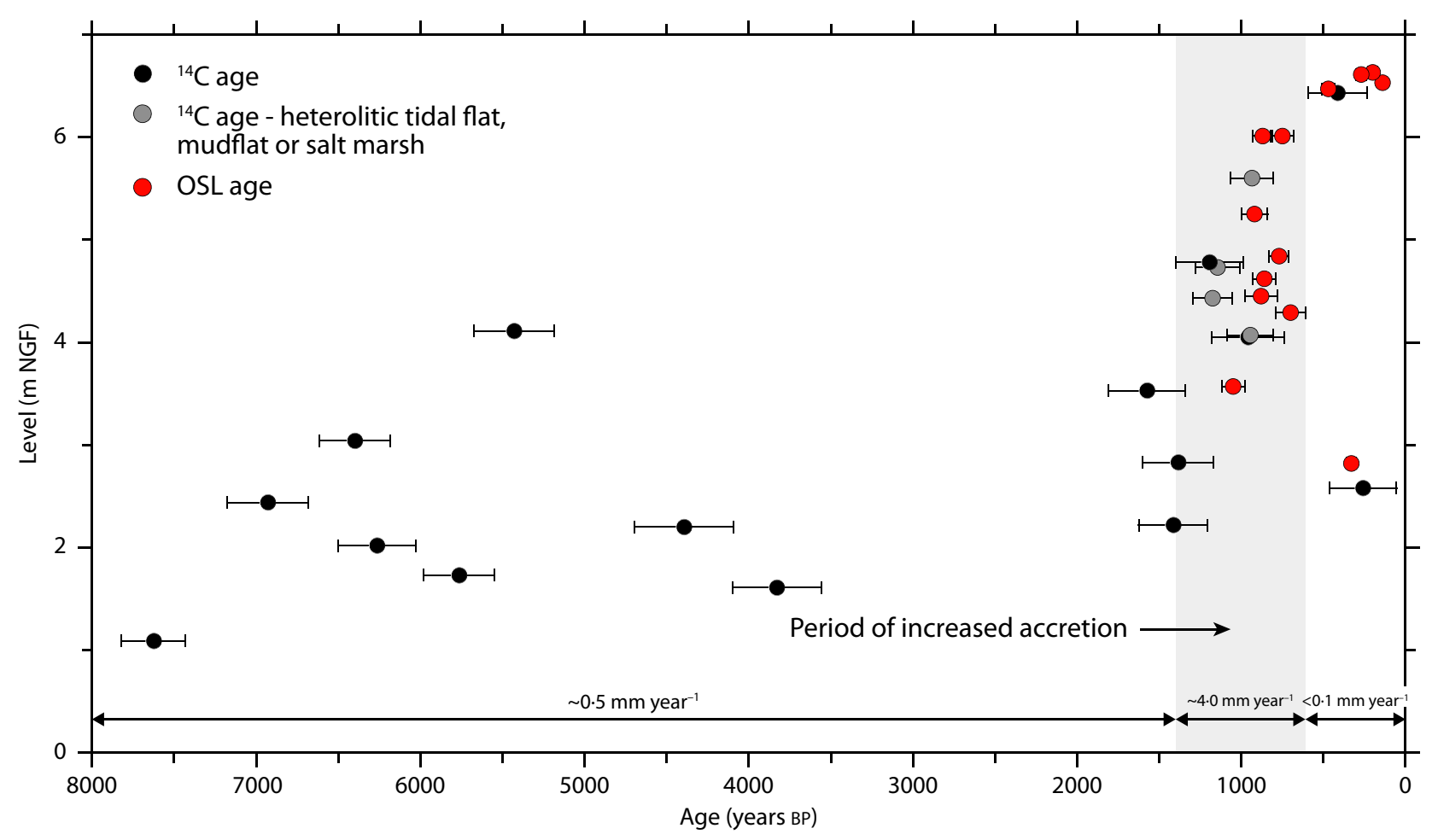

Fig. 15. Age versus depth plot of all non-inverted ages from the cores (cf. Table 2). The plot shows low average long-term rates of accretion between 8000 years and 1400 years ago and increased accretion rates between 1400 years and 600 years ago. The grey dots are ${ }^{14} \mathrm{C}$ ages from heterolithic tidal shoal, mudflat or salt marsh deposits which, in the cores, separate older estuarine deposits from younger estuarine or barrier deposits. NGF, Nivellement Général de la France; OSL, optically stimulated luminescence.
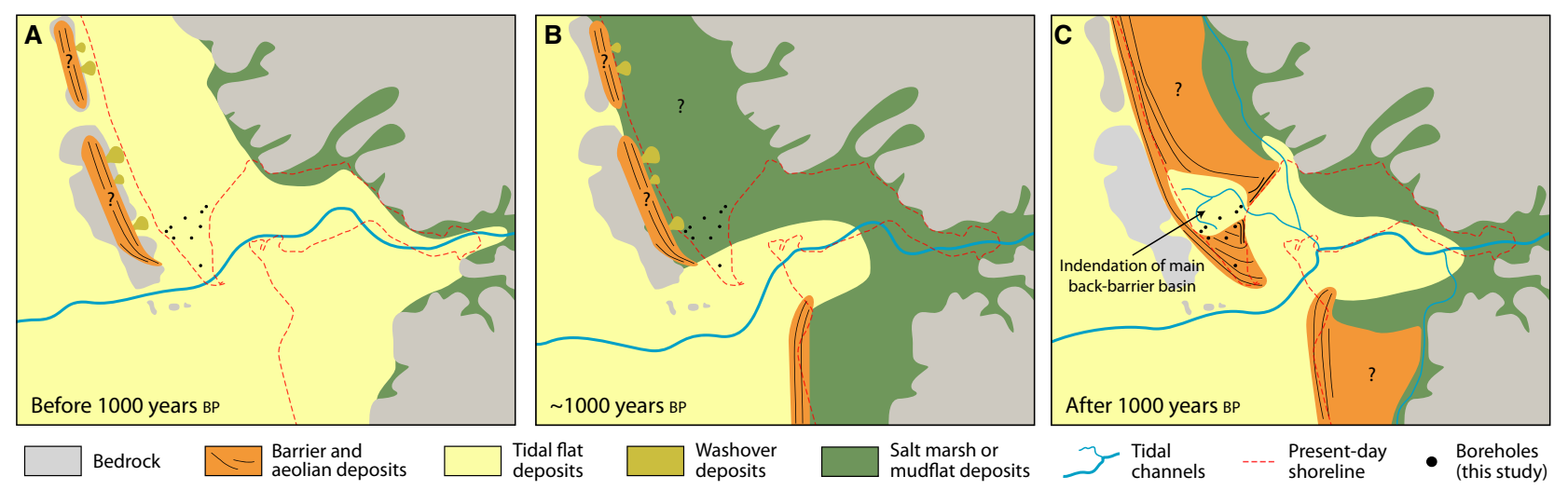

Fig. 16. The palaeogeography of the study area illustrating the evolution from (A) open estuarine embayment about 6000 to 1000 years ago, through (B) widespread salt marsh formation about 1000 years ago, to (C) barrier and spit formation from about 1000 years ago to present.

longshore sediment transport (e.g. Hine, 1979; Allard et al., 2008; Nielsen \& Johannessen, 2009; Lindhorst et al., 2010). Dominant waves from west and north-west approach the north-west/ south-east trending coast at an oblique angle of about $40^{\circ}$. This causes the spit to grow by clinoformal progradation in a down-drift direction
(Fig. 18A and B). Similar to spits in wave-dominated settings (e.g. Nielsen et al., 1988; Aagaard et al., 2004a; Houser \& Greenwood, 2007; Lindhorst et al., 2008), wave-induced currents also generate cross-shore sediment transport in the form of swash bars. According to the direction of wave propagation at the spit terminus, swash 

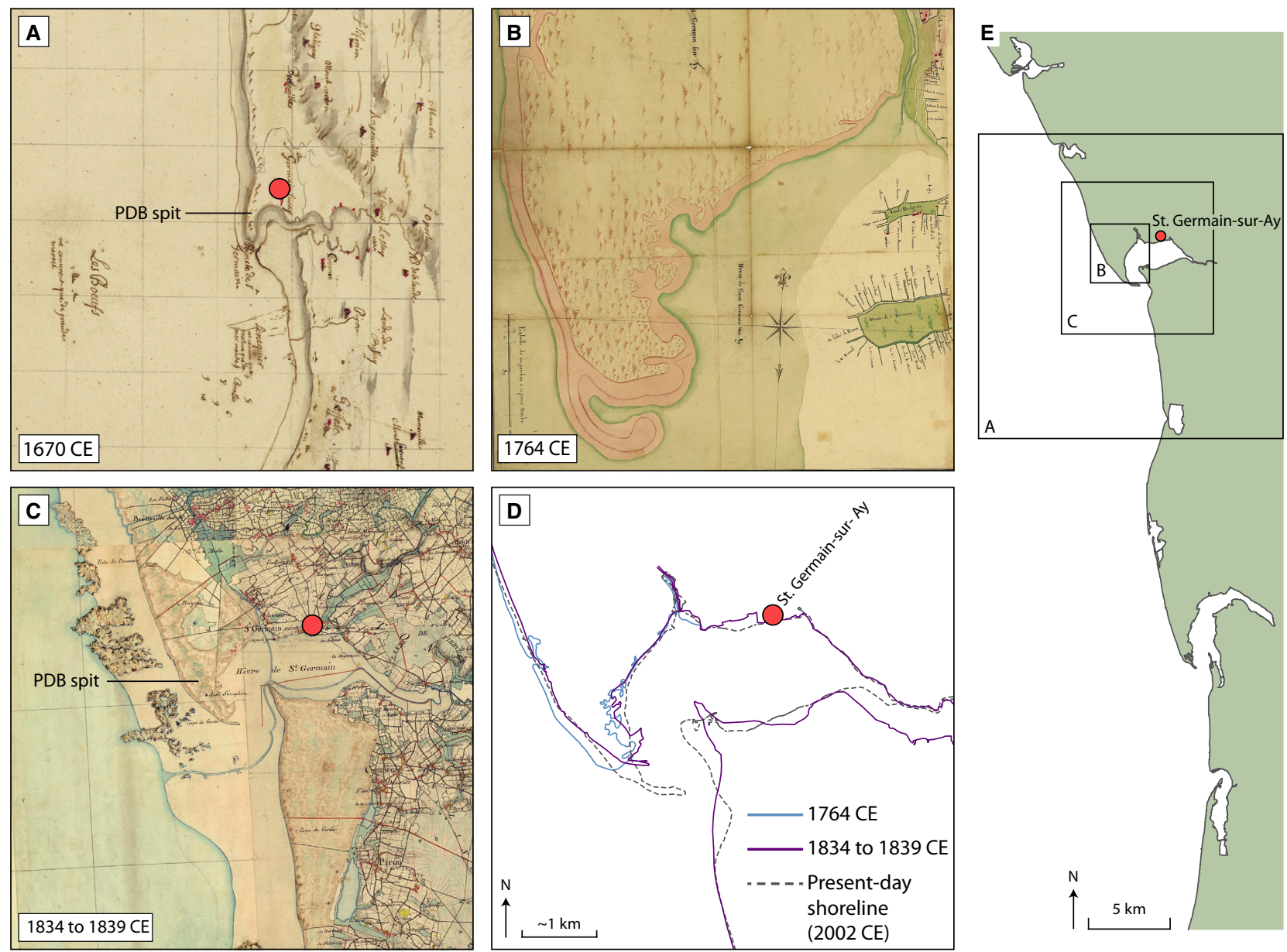

Fig. 17. Historical maps illustrating the evolution of the Pointe du Banc (PDB) spit and Havre de Lessay estuary: (A) de Clerville's map from $1670 \mathrm{CE}$; (B) a map from 1764 CE (unknown author) and (C) from 1834 to 1839 CE (unknown author). The red dot in (A), (C), (D) and (E) shows the position of the village of St. Germain-sur-Ay as indicated in the maps. (D) Shoreline evolution as inferred from the maps in (B) and (C). (E) The modern western shoreline of the Cotentin peninsula. The squares show the approximate spatial extent of the three maps in (A) to (C).

bar foresets can dip landward (i.e. northward) and alongshore (i.e. eastward) (Fig. 18B and C). Due to hypertidal conditions and the shallow water depth in the tidal channel fronting the spit, the swash zone extends across the entire height of the PDB spit terminus, and thus the spit does not encompass a permanently subaqueous spit platform characteristic of microtidal spits (cf. Meistrell, 1972; Nielsen et al., 1988). At the base of the spit platform, swash bars form and migrate landward and upward towards the subaerial beach. Consequently, swash bar foresets are observed downlapping the spit clinoforms from its distal to proximal part (Fig. 18B). The preservation of the swash bar foresets from the base of the spit platform and to its top is only possible in environments with large tidal ranges. This is in contrast to spits located in more wave-dominated settings with less tidal influence where swash bar foresets are associated predominantly with the upper intertidal zone (Nielsen \& Johannessen, 2009).

In contrast to spits located in wave-dominated settings, which mainly grow by longshore and cross-shore wave processes, the PDB spit grew in a landward direction by tide-induced sedimentary processes on the landward side of the spit (Fig. 18). When the water in the estuary is forced seaward during ebb, the spit terminus blocks the flow. To exit the estuary the water is deflected towards the east along the spit terminus (Fig. 18A). This causes tidal dunes to migrate up, across and along the landward side of the spit terminus and causes the spit to widen in a landward direction (Fig. 9, RU6). 


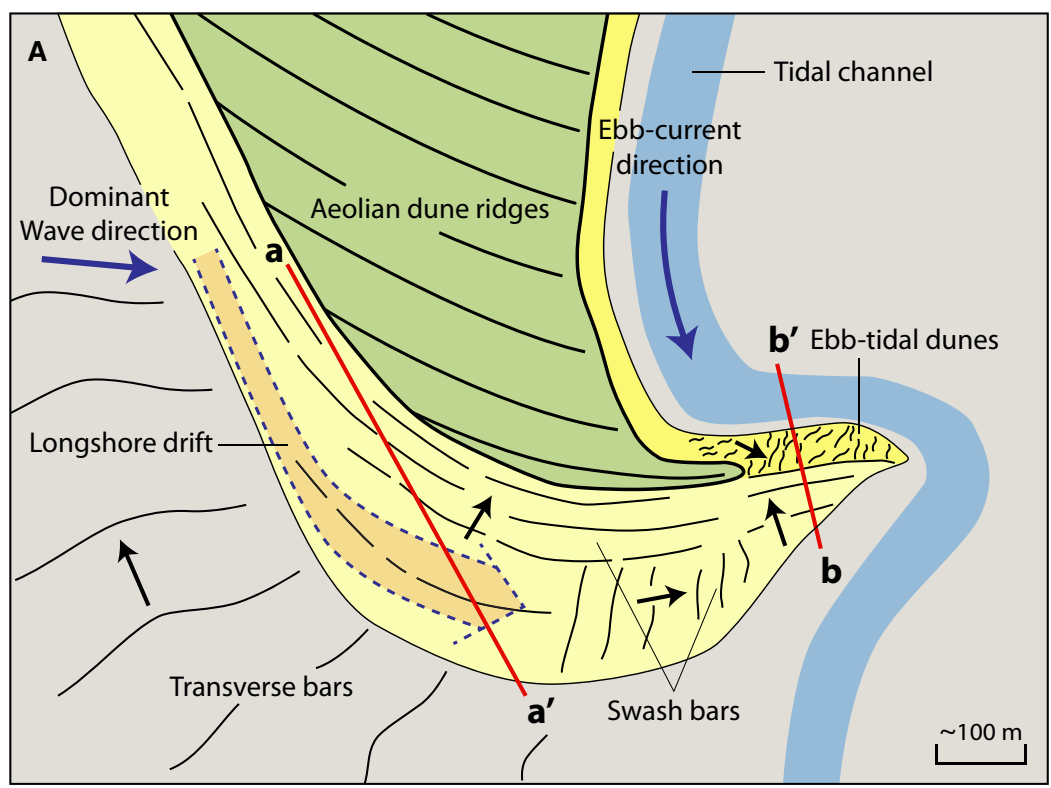

B

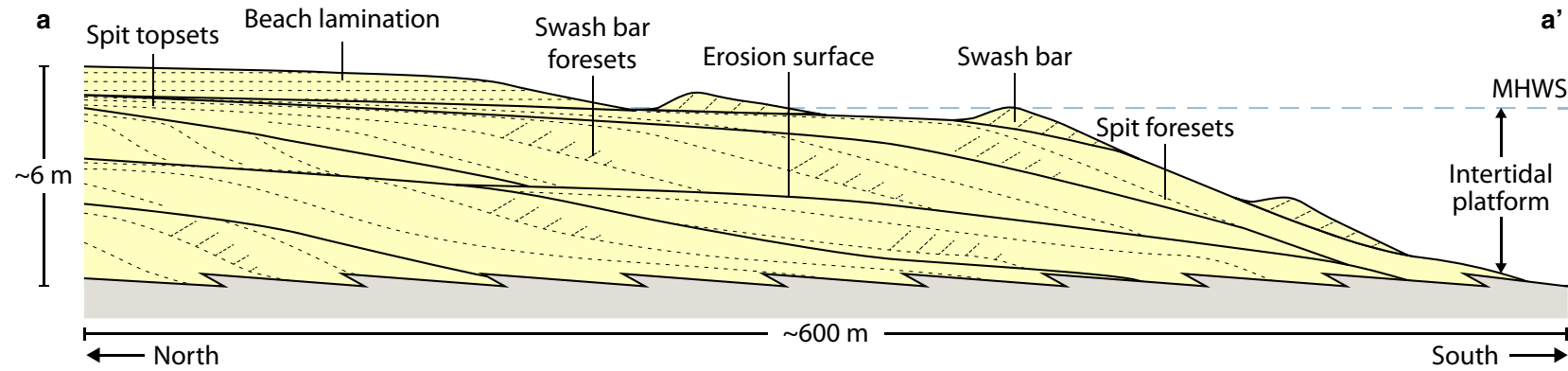

C

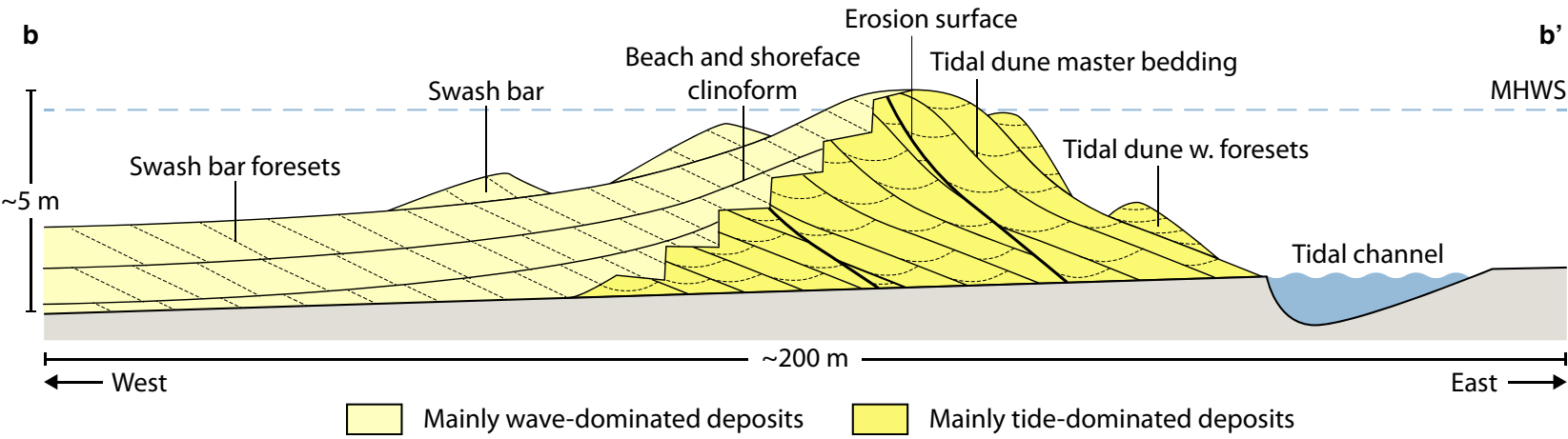

Fig. 18. Morpho-sedimentary model for the Pointe du Banc spit terminus. (A) The schematic map shows how the ebb current causes tidal dunes to migrate up and along the landward side of the spit terminus. On the seaward side of the spit terminus, incoming waves result in landward and alongshore migration of swash bars. The black arrows indicate the main directions of bar and dune migration. (B) and (C) Schematic cross-sections a- $\mathrm{a}^{\prime}$ and $\mathrm{b}-\mathrm{b}^{\prime}$ showing the resulting facies architecture. The geometrical configuration in (B) corresponds to RU5, and in (C) corresponds to RU6 and RU7. Note that the three-dimensional ebb-tidal dunes in (A) migrate in a direction parallel to oblique to the length of the landward slope of the spit terminus. The resulting tidal dune foresets thus appear as troughs between the bounding surfaces and are directed out of the plane of the section. Also note that crosssections are not to scale and are vertically exaggerated. MHWS, mean high water spring. 
Several prominent erosion surfaces are observed in the spit terminus stratigraphy (Fig. 18B and C). These erosion surfaces formed by lateral migration of tidal channels in the estuary and estuary mouth, resulting in lateral erosion of the landward-facing side and headward erosion of the spit terminus. Figure 7 shows how the mouth channel was laterally displaced about $1 \mathrm{~km}$ in 12 years from a location in the eastern part of the estuary mouth in $1998 \mathrm{CE}$ to the western part in $2010 \mathrm{CE}$. With time-averaged long-term migration rates in the order of $80 \mathrm{~m}$ year $^{-1}$, the mouth channel causes spit growth to be highly discontinuous. Furthermore, the location of the estuarine mouth channel appears to influence the curvature of the spit terminus by controlling available space for spit growth in the estuary mouth. The modern PDB spit terminus developed from 1998 to $2014 \mathrm{CE}$ from a relatively long to a relatively curved and short spit terminus (Fig. 7). The change in spit curvature is concurrent with the shift in channel location from the eastern to the western part of the estuary mouth. The preservation potential of the spit terminus is probably related to its length and curvature. When the spit attains a relatively long and straight form, the spit becomes more exposed to wave and tidal forces, which can erode and breach the spit terminus, whereas a spit with a high curvature is more protected from wave action within the estuary but may be more exposed to erosion from the ebb tidal flow.

\section{Key controls on long-term sediment supply}

The evolution at the west coast of the Cotentin peninsula is controlled by a complex set of feedback mechanisms between wave and tidal dynamics, tidal range, storminess and the largescale inherited topography of the coast, which ultimately determine changes in sediment supply to the coast. Hence, changes in controlling mechanisms of sediment supply can have largescale implications for coastal evolution (e.g. Hampson \& Storms, 2003; Fruergaard et al., 2018; Raff et al., 2018). Given the fact that the depositional mode of the PDB spit system changed from transgression to regression $\mathrm{Ca}$ 1000 years ago during a period of constant RSL rise (Lambeck, 1997; Goslin et al., 2015), sediment supply to the coast must have increased, resulting in a positive sediment budget.

Tide-generated, and in particular longshore sediment transport, processes control sediment supply to spits (Levoy et al., 2001; Aagaard et al., 2004b; Ashton \& Murray, 2006; Allard et al., 2008) and determine the long-term sediment budgets of hypertidal coasts. Shifts in the angle of wave incidence relative to the shoreline and increased windiness or storminess are common explanations of changes in longshore sediment transport rates (Aagaard \& Sørensen, 2013; Poirier et al., 2017; Sander et al., 2018) and Goy et al. (1996) documented how a sudden change from coastal aggradation to progradation resulted from changes in the prevailing wind direction. Because the PDB spit is located in the wave shadow of the Channel Islands, with refraction and diffraction effects, it is difficult to evaluate the impact of shifting incident wave angles on net alongshore transport rates (Fig. 1B). Viewed in a regional climatic context, the authors think that an increase in windiness or storminess is a better explanation for the shift from transgressive to progradational mode of the PDB spit. At the Bay of Mont Saint-Michel, located $c a 60 \mathrm{~km}$ south of the study site (Fig. 1B), Billeaud et al. (2009) found stratigraphic evidence for shifting periods of storminess along the coast. One of these stormy periods was dated to 1200 to 1000 years BP (Billeaud et al., 2009), which coincides with the period of intense sediment accumulation and increased sediment supply found in this study (Fig. 15). Other explanations to consider are changes in the updrift coastal configuration. If an updrift sediment sink (such as an estuary) becomes filled and sediment, which used to be trapped in the sink, is bypassed or if updrift coastal erosion increases, for example in response to changes in hydrodynamics. Such situations would place a greater amount of sediment into the longshore drift system and lead to an increased sediment supply to downdrift sites. The latter mechanism has been shown to be responsible for episodic progradation of the Sandy Hook barrier spit on the US Atlantic coast (Allen, 1981).

Coastal storms often cause dune erosion and shoreline retreat (e.g. Sallenger, 2000; Masselink \& van Heteren, 2014). Less common are storms that add sediment to the coast (Aagaard et al., 2004a; Fruergaard et al., 2013). However, several studies of wave-dominated, long-drift barrier coasts suggest that sediment supply and depositional locus were largely controlled by the largescale topography and curvature of the coast (e.g. Roy et al., 1980; Riggs et al., 1995; Cooper et al., 2012). In a number of more recent studies from 
the Danish Wadden Sea it was argued that sediment eroded during storms is transported from protruding sections of the coast towards embayed sections where it deposits (Fruergaard et al., 2015a,b, 2018). Protruding sections are thus retreating whereas embayed sections are prograding. The PDB spit is subject to longshore drift convergence because of its position in the inner part of the large-scale embayment formed between the headlands of Barneville-Carteret and Gouville-sur-Mer (Fig. 1B). The interpretation herein suggests that during the period of increased storminess approximately 1100 years ago, sediment was eroded from the coast north and, to a lesser extent, south of the PDB, and transported towards, and deposited along the coast of the PDB. This contributed to an excess sediment budget, rapid accretion and construction of the spit.

The hypertidal west coast of Cotentin and the microtidal Danish Wadden Sea coast may not be directly comparable in terms of sediment transport processes because of the substantial difference in tidal energy. The large tidal range along the Cotentin coast results in a rapid up and down shift of sea-level position across the foreshore profile. Hence, the duration of storm wave processes acting along the profile is short and thereby reduces morphological storm impact (Kroon \& Masselink, 2002; Morton, 2002). Only storms approximately coincident with high tide can induce substantial erosion of beaches and dunes, and release sediment for littoral drift. Despite these considerations, the present study suggests that evolution of barrier systems in hypertidal coastal environments are mainly governed by changes in wave dynamics and, despite a complex composite architecture consisting of both wave-dominated and tide-dominated bodies, they preserve information on past climatic changes and depositional controls.

\section{CONCLUSIONS}

- The geomorphology, stratigraphy and internal sedimentary architecture of the Pointe du Banc (PDB) barrier system along the hypertidal Cotentin peninsula coastal zone, English Channel, north-western France, was constructed from geodata, boreholes, ground penetrating radar profiles, ${ }^{14} \mathrm{C}$ and optically stimulated luminescence age data and historical maps. Despite the hypertidal conditions of the study site, the reconstruction shows that the sedimentary architecture of the barrier system is predominantly composed of wave-dominated depositional elements. However, tidal influence is clearly recorded and mainly related to the tidal inlet dynamics.

- A sedimentological model for barrier spit terminus development under hypertidal conditions is presented. The model describes how the spit extends downdrift by clinoformal progradation resulting from littoral drift and due to swash bar welding along the distal end of the barrier. Lateral and vertical growth of the spit terminus results from sediment convergence due to landward migration of swash bars and seaward migration of tidal dunes.

- The stratigraphy and architecture of the investigated spit is characterised by both wavedominated and tide-dominated strata. Wavedominated strata consist of clinoforms dipping seaward and in a downdrift direction, and swash bar foresets dipping landward. Tidedominated strata consist of tidal master bedding dipping landward with ebb-tidal dune foresets dipping in a seaward and downdrift direction.

- The preservation potential of the spit terminus relates to spit curvature. When the curvature is high, the preservation potential is relatively higher than when the spit terminus is straight in a downdrift direction. In the latter case, it is more likely that erosion of the updrift end will favour breaching and formation of a detached spit. A modern example shows that the detached spit terminus will then be incorporated into the flood tidal delta, evolving as a swash bar.

- At a long-term timescale (late Holocene), wave-induced processes appear to be the dominant factor controlling the formation and evolution of spits located in hypertidal environments with changes in storminess inducing variations in alongshore and crossshore sediment supply.

\section{ACKNOWLEDGEMENTS}

Funding for this research was provided by the French Ministry for Sustainable Development as part of the LITEAU program (BLINIS project 2100949 750, including C. Poirier post-doctoral grant), by the Basse Normandie Regional Council, and by the Carlsberg Foundation, Denmark (COASTEVENT; grant nos. CF14-0173 and CF15-0254) to M. Fruergaard. We warmly thank 
F. Lelong and S. Haquin from M2C for managing and performing the vibracoring campaign, and A.S. Murray from the Nordic Laboratory for Luminescence Dating, Aarhus University for valuable discussions on the OSL data set. Finally, we would like to acknowledge the very knowledgeable and detailed reviews of R.W. Dalrymple., C.J. Hein and B.W. Flemming along with remarks from Associate Editor Charlie Bristow whose constructive comments greatly helped to improve this paper.

\section{REFERENCES}

Aagaard, T. and Sørensen, P. (2013) Sea level rise and the sediment budget of an eroding barrier on the Danish North Sea coast. J. Coastal Res., Special issue 65, 434-439.

Aagaard, T., Davidson-Arnott, R., Greenwood, B. and Nielsen, J. (2004a) Sediment supply from shoreface to dunes: linking sediment transport measurements and long-term morphological evolution. Geomorphology, 60, 205-224.

Aagaard, T., Nielsen, J., Jensen, S.G. and Friderichsen, J. (2004b) Longshore sediment transport and coastal erosion at Skallingen, Denmark. Geogr. Tidsskr.-Danish J. Geogr., 104, 5-14.

Allard, J., Bertin, X., Chaumillon, E. and Pouget, F. (2008) Sand spit rhythmic development: a potential record of wave climate variations? Arçay Spit, western coast of France. Mar. Geol., 253, 107-131.

Allen, J.R. (1981) Beach erosion as a function of variations in the sediment budget, Sandy Hook, New Jersey, U.S.A. Earth Surf. Proc. Land., 6, 139-150.

Allen, J.R.L. (1980) Sand waves: a model of origin and internal structure. Sed. Geol., 26, 281-328.

Archer, A.W. (2013) World's highest tides: Hypertidal coastal systems in North America, South America and Europe. Sed. Geol., 284, 1-25.

Ashton, A.D. and Murray, A.B. (2006) High-angle wave instability and emergent shoreline shapes: 1. Modeling of sand waves, flying spits, and capes. J. Geophys. Res. Earth Surf., 111, F04011.

Avoine, J. and Larsonneur, C. (1987) Dynamics and behaviour of suspended sediment in macrotidal estuaries along the south coast of the English Channel. Cont. Shelf Res., 7, 1301-1305.

Banque-Hydro (2018) Station I6983010, l'Ay à Ancteville. Data provided by DREAL Basse-Normandie available at www.hydro.eaufrance.fr.

Belknap, D.F. and Kraft, J.C. (1985) Influence of antecedent geology on stratigraphic preservation potential and evolution of Delaware barrier systems. Mar. Geol., 63, 235-262.

Billeaud, I., Tessier, B., Lesueur, P. and Caline, B. (2007) Preservation potential of highstand coastal sedimentary bodies in a macrotidal basin: example from the Bay of Mont-Saint-Michel, NW France. Sed. Geol., 202, 754-775.

Billeaud, I., Tessier, B. and Lesueur, P. (2009) Impacts of late Holocene rapid climate changes as recorded in a macrotidal coastal setting (Mont-Saint-Michel Bay, France). Geology, 37, 1031-1034.

Billy, J., Robin, N., Hein, C.J., Certain, R. and FitzGerald, D.M. (2014) Internal architecture of mixed sand-and-gravel beach ridges: Miquelon-Langlade Barrier, NW Atlantic. Mar. Geol., 357, 53-71.

Bøtter-Jensen, L., Bulur, E., Duller, G.A.T. and Murray, A.S. (2000) Advances in luminescence instrument systems. Radiat. Meas., 32, 523-528.

Bøtter-Jensen, L., Bulur, E., Murray, A.S. and Poolton, N.R.J. (2002) Enhancements in luminescence measurement techniques. Radiat. Prot. Dosimetry., 101, 119-124.

Bourcart, J. and Charlier, R.H. (1959) The Tangue, a "nonconformin" sediment. Geol. Soc. Am. Bull., 70, 565-568.

Bristow, C. (2009) Ground penetrating radar in aeolian dune sands. In: Ground Penetrating Radar Theory and Applications (Ed. H.M. Jol), pp. 271-297. Elsevier, Amsterdam.

Bristow, C.S., Neil Chroston, P. and Bailey, S.D. (2000) The structure and development of foredunes on a locally prograding coast: insights from ground-penetrating radar surveys, Norfolk, UK. Sedimentology, 47, 923-944.

Church, J.A., Clark, P.U., Cazenave, A., Fregory, J.M., Jevrejeva, S., Levermann, A., Merrifield, M.A., Milne, G.A., Nerem, R.S., Nunn, P.D., Payne, A.J., Pfeffer, W.T., Stammer, D. and Unnikrishnan, A.S. (2013) Sea Level Change. In: Climate Change 2013: The Physical Science Basis. Contribution of Working Group I to the Fifth Assessment Report of the Intergovernmental Panel on Climate Change (Eds T.F.Q. Stocker, G.-K. Plattner, M. Tignor, S.K. Allen, J. Boschung, A. Nauels, Y. Xia, V. Bex and P.M. Midgley), pp. 1137-1216. Cambridge University Press, Cambridge.

Clemmensen, L.B., Pye, K., Murray, A. and Heinemeier, J. (2001) Sedimentology, stratigraphy and landscape evolution of a Holocene coastal dune system, Lodbjerg, NW Jutland, Denmark. Sedimentology, 48, 3-27.

Clifton, H.E. (1969) Beach lamination - Nature and origin. Mar. Geol., 7, 553.

Colman, S.M. and Mixon, R.B. (1988) The record of major quaternary sea-level changes in a large coastal plain estuary, Chesapeake Bay, Eastern United States. Palaeogeogr. Palaeoclimatol. Palaeoecol., 68, 99-116.

Cooper, J.A.G., Jackson, D.W.T., Dawson, A.G., Dawson, S., Bates, C.R. and Ritchie, W. (2012) Barrier islands on bedrock: a new landform type demonstrating the role of antecedent topography on barrier form and evolution. Geology, 40, 923-926.

Cooper, J.A.G., Green, A.N. and Loureiro, C. (2018) Geological constraints on mesoscale coastal barrier behaviour. Global Planet. Change, 168, 15-34.

Dabrio, C.J. (1982) Sedimentary structures generated on the foreshore by migrating ridge and runnel systems on microtidal and mesotidal coasts of S. Spain. Sed. Geol., 32, 141-151.

Dalrymple, R.W. (1984) Morphology and internal structure of sandwaves in the Bay of Fundy. Sedimentology, 31, 365-382.

Dalrymple, R.W., Mackay, D.A., Ichaso, A.A. and Choi, K.S. (2012) Processes, morphodynamics, and facies of tidedominated estuaries. In: Principles of Tidal Sedimentology (Eds R.A. Davis Jr and R.W. Dalrymple), pp. 79-108. New York, Heidleberg, Springer Science+Business Media BV.

Daly, J., McGeary, S. and Krantz, D.E. (2002) Groundpenetrating radar investigation of a late Holocene spit complex: Cape Henlopen, Delaware. J. Coastal Res., 18, 274-286.

Davis, J.L. (1964) A morphogenic approach to world shorelines. Z. Geomorphol., 8, 27-42. 
Dillenburg, S.R., Roy, P.S., Cowell, P.J. and Tomazelli, L.J. (2000) Influence of antecedent topography on coastal evolution as tested by the shoreface translation-barrier model (STM). J. Coastal Res., 16, 71-81.

Doré, F. and Poncet, J. (1974) La Haye du Puits. In: Carte géologique à 1/50 000 et notice explicative. BRGM, France.

Dougherty, A.J., FitzGerald, D.M. and Buynevich, I.V. (2004) Evidence for storm-dominated early progradation of Castle Neck barrier, Massachusetts, USA. Mar. Geol., 210, 123-134.

Dujardin, J.-R. and Bano, M. (2013) Topographic migration of GPR data: examples from Chad and Mongolia. CR Geosci., 345, 73-80.

Ehrhold, A. (1999) Dynamique de comblement d'un bassin sédimentaire soumis à un régime mégatidal. L'exemple de la Baie du Mont-Saint-Michel. Unpublished PhD thesis, University of Caen-Basse Normandie, $294 \mathrm{pp}$.

Evans, O.F. (1942) The origin of spits, bars, and related structures. J. Geol., 50, 20.

Fitzgerald, D.M., Penland, S. and Nummedal, D. (1984) Control of barrier island shape by inlet sediment bypassing: East Frisian Islands, West Germany. Mar. Geol., 60, 355-376.

Fruergaard, M. and Kroon, A. (2016) Morphological response of a barrier island system on a catastrophic event: the $\mathrm{AD} 1634$ North Sea storm. Earth Surf. Proc. Land., 41, 420-426.

Fruergaard, M., Andersen, T.J., Johannessen, P.N., Nielsen, L.H. and Pejrup, M. (2013) Major coastal impact induced by a 1000-year storm event. Sci. Rep., 3, 1-7.

Fruergaard, M., Andersen, T.J., Nielsen, L.H., Johannessen, P.N., Aagaard, T. and Pejrup, M. (2015a) High-resolution reconstruction of a coastal barrier system: impact of Holocene sea-level change. Sedimentology, 62, 928-969.

Fruergaard, M., Møller, I., Johannessen, P.N., Nielsen, L.H., Andersen, T.J., Nielsen, L., Sander, L. and Pejrup, M. (2015b) Stratigraphy, evolution, and controls of a Holocene transgressive-regressive barrier island under changing sea level: Danish North Sea coast. J. Sed. Res., 85, 820-844.

Fruergaard, M., Johannessen, P.N., Nielsen, L.H., Nielsen, L., Møller, I., Andersen, T.J., Piasecki, S. and Pejrup, M. (2018) Sedimentary architecture and depositional controls of a Holocene wave-dominated barrier-island system. Sedimentology, 65, 1170-1212.

Garrison, J.R., Williams, J., Miller, S.P., Weber, E.T., McMechan, G. and Zeng, X.X. (2010) Ground-penetrating radar study of North Padre Island: implications for barrier island internal architecture, model for growth of progradational microtidal barrier islands, and Gulf of Mexico sea-level cyclicity. J. Sed. Res., 80, 303-319.

Goslin, J., Van Vliet Lanoë, B., Spada, G., Bradley, S., Tarasov, L., Neill, S. and Suanez, S. (2015) A new Holocene relative sea-level curve for western Brittany (France): insights on isostatic dynamics along the Atlantic coasts of north-western Europe. Quatern. Sci. Rev., 129, 341-365.

Goy, J., Zazo, C., Dabrio, C.J., Lario, J., Borja, F., Sierro, F.J. and Flores, J. (1996) Global and regional factors controlling changes of coastlines in Southern Iberia (Spain) during the holocene. Quatern. Sci. Rev., 15, 773-780.

Grinsted, A., Moore, J.C. and Jevrejeva, S. (2013) Projected Atlantic hurricane surge threat from rising temperatures. Proc. Natl Acad. Sci. USA, 110, 5369-5373.

Guérin, G., Mercier, N. and Adamiec, G. (2011) Dose-rate conversion factors: Update.Ancent TL, 29, 5-8.
Hampson, G.J. and Storms, J.E. (2003) Geomorphological and sequence stratigraphic variability in wave-dominated, shoreface-shelf parasequences. Sedimentology, 50, 667-701.

Hine, A.C. (1979) Mechanisms of berm development and resulting beach growth along a barrier spit complex. Sedimentology, 26, 333.

Houser, C. and Greenwood, B. (2007) Onshore migration of a swash bar during a storm. J. Coastal Res., 1-14.

Hunter, R.E. (1977) Basic types of stratification in small eolian dunes. Sedimentology, 24, 361-387.

Isla, F.I., Vilas, F.E., Bujalesky, G.G., Ferrero, M., Bonorino, G.G. and Miralles, A.A. (1991) Gravel drift and wind effects on the macrotidal San Sebastian Bay, Tierra del Fuego, Argentina. Mar. Geol., 97, 211-224.

Jones, I.F. and Levy, S. (1987) Signal-to-noise ratio enhancement in multichannel seismic data via the Karhunen-Loéve transform. Geophys. Prospect., 35, 12-32.

Kocurek, G.A. (1996) Desert aeolian systems. In: Sedimentary Environments: processes, Facies and Stratigraphy (Ed. H.G. Reading), pp. 125-153. Blackwell Science, Oxford.

Kraft, J.C. (1971) Sedimentary facies patterns and geologic history of a Holocene marine transgression. Geol. Soc. Am. Bull., 82, 2131-2158.

Kroon, A. and Masselink, G. (2002) Morphodynamics of intertidal bar morphology on a macrotidal beach under low-energy wave conditions, North Lincolnshire, England. Mar. Geol., 190, 591-608.

Lambeck, K. (1997) Sea-level change along the French Atlantic and Channel coasts since the time of the Last Glacial Maximum. Palaeogeogr. Palaeoclimatol. Palaeoecol., 129, 1-22.

Larsonneur, C. (1994) The Bay of Mont-Saint-Michel: a sedimentation model in a temperate macrotidal environment. Senckenb. Marit, 24, 3-63.

Lessa, G. and Masselink, G. (2006) Evidence of a MidHolocene sea level highstand from the sedimentary record of a Macrotidal Barrier and Paleoestuary System in Northwestern Australia. J. Coastal Res., 100-112.

Levoy, F., Anthony, E.J., Monfort, O. and Larsonneur, C. (2000) The morphodynamics of megatidal beaches in Normandy, France. Mar. Geol., 171, 39-59.

Levoy, F., Monfort, O. and Larsonneur, C. (2001) Hydrodynamic variability on megatidal beaches, Normandy, France. Cont. Shelf Res., 21, 563-586.

Levoy, F., Anthony, E.J., Monfort, O., Robin, N. and Bretel, P. (2013) Formation and migration of transverse bars along a tidal sandy coast deduced from multi-temporal Lidar datasets. Mar. Geol., 342, 39-52.

Lindhorst, S., Betzler, C. and Hass, H.C. (2008) The sedimentary architecture of a Holocene barrier spit (Sylt, German Bight): swash-bar accretion and storm erosion. Sed. Geol., 206, 1-16.

Lindhorst, S., Furstenau, J., Hass, H.C. and Betzler, C. (2010) Anatomy and sedimentary model of a hooked spit (Sylt, southern North Sea). Sedimentology, 57, 935-955.

Mallinson, D.J., Smith, C.W., Culver, S.J., Riggs, S.R. and Ames, D. (2010) Geological characteristics and spatial distribution of paleo-inlet channels beneath the outer banks barrier islands, North Carolina, USA. Estuar. Coast. Shelf Sci., 88, 175-189.

Masselink, G. and van Heteren, S. (2014) Response of wavedominated and mixed-energy barriers to storms. Mar. Geol., 352, 321-347. 
Meistrell, F.J. (1972) The spit-platform concept: laboratory observation of spit development. In: Spits and Bars (Ed. M.L. Schwartz), pp. 225-283. Dowden, Hutchinson \& Ross, Stroudsberg, PA.

Montreuil, A.-L., Levoy, F., Bretel, P. and Anthony, E.J. (2014) Morphological diversity and complex sediment recirculation on the ebb delta of a macrotidal inlet (Normandy, France): a multiple LiDAR dataset approach. Geomorphology, 219, 114-125.

Morton, R.A. (2002) Factors controlling storm impacts on coastal barriers and beaches - A preliminary basis for near real-time forecasting. J. Coastal Res., 18, 486-501.

Morton, R.A. and Sallenger, A.H. (2003) Morphological impacts of extreme storms on sandy beaches and barriers. J. Coastal Res., 19, 560-573.

Murray, A.S. and Wintle, A.G. (2000) Luminescence dating of quartz using an improved single-aliquot regenerativedose protocol. Radiat. Meas., 32, 57-73.

Murray, A.S. and Wintle, A.G. (2003) The single aliquot regenerative dose protocol: potential for improvements in reliability. Radiat. Meas., 37, 377-381.

Murray, A.S., Marten, R., Johnston, A. and Martin, P. (1987) Analysis for naturally-occurring radionuclides at environmental concentrations by gamma spectrometry. J. Radioanal. Nucl. Chem. , 115, 263-288.

Neal, A. (2004) Ground-penetrating radar and its use in sedimentology: principles, problems and progress. Earth Sci. Rev., 66, 261-330.

Neal, A. and Roberts, C.L. (2000) Applications of groundpenetrating radar (GPR) to sedimentological, geomorphological and geoarchaeological studies in coastal environments. Geol. Soc. London Spec. Publ., 175, 139-171.

Nielsen, L.H. and Johannessen, P.N. (2009) Facies architecture and depositional processes of the HoloceneRecent accretionary forced regressive Skagen spit system, Denmark. Sedimentology, 56, 935-968.

Nielsen, L.H., Johannessen, P.N. and Surlyk, F. (1988) A late Pleistocene coarse-grained spit-platform sequence in Northern Jylland, Denmark. Sedimentology, 35, 915-938.

Nielsen, L., Møller, I., Nielsen, L.H., Johannessen, P.N., Pejrup, M., Andersen, T.J. and Korshøj, J.S. (2009) Integrating ground-penetrating radar and borehole data from a Wadden Sea barrier island. J. Appl. Geophys., 68, 47-59.

Oliver, T.S.N., Donaldson, P., Sharples, C., Roach, M. and Woodroffe, C.D. (2017) Punctuated progradation of the Seven Mile Beach Holocene barrier system, southeastern Tasmania. Mar. Geol., 386, 76-87.

Poirier, C., Tessier, B., Chaumillon, É., Bertin, X., Fruergaard, M., Mouazé, D., Noël, S., Weill, P. and Wöppelmann, G. (2017) Decadal changes in North Atlantic atmospheric circulation patterns recorded by sand spits since 1800 CE. Geomorphology, 281, 1-12.

Raff, J.L., Shawler, J.L., Ciarletta, D.J., Hein, E.A., LorenzoTrueba, J. and Hein, C.J. (2018) Insights into barrier-island stability derived from transgressive/regressive state changes of Parramore Island, Virginia. Mar. Geol., 403, 1-19.

Reimann, T., Tsukamoto, S., Harff, J., Osadczuk, K. and Frechen, M. (2011) Reconstruction of Holocene coastal foredune progradation using luminescence dating - An example from the Swina barrier (southern Baltic Sea, NW Poland). Geomorphology, 132, 1-16.

Reimer, P.J. and Reimer, R.W. (2001) A marine reservoir correction database and on-line interface. Radiocarbon, 43, $461-463$
Reimer, P.J., Bard, E., Bayliss, A., Beck, J.W., Blackwell, P.G., Bronk Ramsey, C., Buck, C.E., Cheng, H., Edwards, R.L., Friedrich, M., Grootes, P.M., Guilderson, T.P., Haflidason, H., Hajdas, I., Hatté, C., Heaton, T.J., Hoffmann, D.L., Hogg, A.G., Hughen, K.A., Kaiser, K.F., Kromer, B., Manning, S.W., Niu, M., Reimer, R.W., Richards, D.A., Scott, E.M., Southon, J.R., Staff, R.A., Turney, C.S.M. and van der Plicht, J. (2013) IntCal13 and Marine13 radiocarbon age calibration curves 050,000 years cal вр. Radiocarbon, 55, 1869-1887.

Reineck, H.E. and Wunderlich, F. (1968) Classification and origin of flaser and lenticular bedding. Sedimentology, 11, 99-104.

Riggs, S.R., Cleary, W.J. and Snyder, S.W. (1995) Influence of inherited geologic framework on barrier shoreface morphology and dynamics. Mar. Geol., 126, 213-234.

Robin, N., Levoy, F. and Monfort, O. (2009a) Short term morphodynamics of an intertidal bar on megatidal ebb delta. Mar. Geol., 260, 102-120.

Robin, N., Levoy, F., Monfort, O. and Anthony, E. (2009b) Short-term to decadal-scale onshore bar migration and shoreline changes in the vicinity of a megatidal ebb delta. J. Geophys. Res. Earth Surf., 114.

Roy, P.S., Thom, B.G. and Wright, L.D. (1980) Holocene sequences on an embayed high-energy coast - an evolutionary model. Sed. Geol., 26, 1-19.

Sallenger, A.H. (2000) Storm impact scale for barrier islands. J. Coastal Res., 16, 890-895.

Sander, L., Fruergaard, M., Koch, J., Johannessen, P.N. and Pejrup, M. (2015) Sedimentary indications and absolute chronology of Holocene relative sea-level changes retrieved from coastal lagoon deposits on Samsø, Denmark. Boreas, 44, 706-720.

Sander, L., Hede, M.U., Fruergaard, M., Nielsen, L., Clemmensen, L.B., Kroon, A., Johannessen, P.N., Nielsen, L.H. and Pejrup, M. (2016) Coastal lagoons and beach ridges as complementary sedimentary archives for the reconstruction of Holocene relative sea-level changes. Terra Nova, 28, 43-49.

Sander, L., Pejrup, M., Murray, A.S., Perillo, G.M., Raniolo, L.A. and Fruergaard, M. (2018) Chronology and lateHolocene evolution of Caleta de los Loros, NE Patagonia, Argentina. Holocene, 28, 1276-1287.

Seneviratne, S.I., Nicholls, N., Easterling, D., Goodess, C.M., Kanae, S., Kossin, J., Luo, Y., Marengo, J., McInnes, K., Rahimi, M., Reichstein, M., Sorteberg, A., Vera, C. and Zhang, X. (2012) Changes in climate extremes and their impacts on the natural physical environment. In: Managing the Risks of Extreme Events and Disasters to Advance Climate Change Adaptation. A Special Report of Working Groups I and II of the Intergovernmental Panel on Climate Change (IPCC) (Eds C.B. Field, V. Barros, T.F. Stocker, D. Qin, D.J. Dokken, K.L. Ebi, M.D. Mastrandrea, K.J. Mach, G.-K. Plattner, S.K. Allen, M. Tignor and P.M. Midgley), pp. 109-230. Cambridge University Press, Cambridge.

Sexton, W.J. and Hayes, M.O. (1991) The geologic impact of hurricane hugo and post-storm shoreline recovery along the undeveloped coastline of South Carolina, Dewees Island to the Santee Delta. J. Coastal Res., 16.

SHOM (2013) Références Altimétriques Maritimes - Cotes du Zéro Hydrographique et Niveaux Caractéristiques de la Marée, Service Hydrographique et Océanographique de la Marine (SHOM), France. 
Stuiver, M. and Reimer, P.J. (1993) Extended C-14 data-base and revised Calib 3.0 C-14 age calibration program. Radiocarbon, 35, 215-230.

Stuiver, M., Reimer, P.J. and Reimer, R.W. (2005) CALIB 5.0.2 [WWW program and documentation] www.calib.org.

Tessier, B., Billeaud, I., Sorrel, P., Delsinne, N. and Lesueur, P. (2012) Infilling stratigraphy of macrotidal tidedominated estuaries. Controlling mechanisms: sea-level fluctuations, bedrock morphology, sediment supply and climate changes (The examples of the Seine estuary and the Mont-Saint-Michel Bay, English Channel, NW France). Sed. Geol., 279, 62-73.

Timmons, E.A., Rodriguez, A.B., Mattheus, C.R. and DeWitt, R. (2010) Transition of a regressive to a transgressive barrier island due to back-barrier erosion, increased storminess, and low sediment supply: Bogue Banks, North Carolina, USA. Mar. Geol., 278, 100-114.

Tisnérat-Laborde, N., Paterne, M., Métivier, B., Arnold, M., Yiou, P., Blamart, D. and Raynaud, S. (2010) Variability of the northeast Atlantic sea surface $\Delta 14 \mathrm{C}$ and marine reservoir age and the North Atlantic Oscillation (NAO). Quatern. Sci. Rev., 29, 2633-2646.

Van Heteren, S. and Van De Plassche, O. (1997) Influence of relative sea-level change and tidal-inlet development on barrier-spit stratigraphy, Sandy Neck, Massachusetts. J. Sed. Res., 67, 350-363.

von Storch, H. and Woth, K. (2008) Storm surges: perspectives and options. Sustain. Sci., 3, 33-43.

Weill, P., Tessier, B., Mouaze, D., Bonnot-Courtois, C. and Norgeot, C. (2012) Shelly cheniers on a modern macrotidal flat (Mont-Saint-Michel bay, France) - Internal architecture revealed by ground-penetrating radar. Sed. Geol., 279, 173-186.

Manuscript received 11 July 2018; revision accepted 1 August 2019 